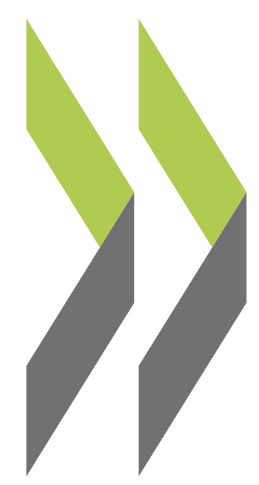

OECD Economics Department Working Papers No. 726

Iceland: Challenging Times for Monetary and Fiscal Andrea de Michelis Policies 


\section{Unclassified}

Organisation de Coopération et de Développement Économiques

Organisation for Economic Co-operation and Development

ECONOMICS DEPARTMENT
ECO/WKP(2009)67

09-Oct-2009

English - Or. English

ICELAND: CHALLENGING TIMES FOR MONETARY AND FISCAL POLICIES

ECONOMICS DEPARTMENT WORKING PAPER No. 726

By Andrea De Michelis

All Economics Department Working Papers are available through the OECD internet website at www.oecd.org/Working_Papers 


\section{ABSTRACT/RESUMÉ}

\section{Iceland: Challenging times for monetary and fiscal policies}

Monetary and fiscal policies face huge challenges: the banking sector has collapsed; the economy is in the midst of a deep recession; the exchange rate has plunged; capital flows have been frozen; inflation is elevated; public debt has risen; source of revenues have disappeared; social needs have increased; and the unemployment insurance fund has been nearly depleted. Against this difficult background, this paper discusses what policy makers should do in order to restore balance in the Icelandic economy and lay out the foundations for a sustainable recovery. The key recommendations are to seek entry in the euro area and implement the fiscal consolidation measures necessary to comply with the IMF programme.

This Working Paper relates to the 2009 Economic Survey of Iceland.

(www.oecd.org/eco/surveys/Iceland)

\section{JEL classification: E21; E42; E52; E62; H51; H52; H60}

Key words: inflation; volatility; inflation targeting; exchange rate targeting; inflation expectations; policy credibility; capital controls; EU; euro area; optimal currency area; fiscal consolidation; taxes; public-sector wages; public investment; fiscal policy framework; efficiency of social spending; student-to-teacher ratio; producer support in agriculture; Iceland.

\section{Islande : Une période délicate pour la politique monétaire et budgétaire}

La politique monétaire et budgétaire est confrontée à de graves problèmes: le système bancaire s'est effondré; l'économie traverse une profonde récession; le taux de change s'est beaucoup déprécié; les mouvements de capitaux se sont interrompus; l'inflation est forte; la dette publique a augmenté; des sources de recettes ont disparu; les besoins sociaux se sont accrus; les ressources du fonds d'assurance chômage sont presque épuisées. Dans ce sombre contexte, cette étude expose ce que les autorités devraient faire pour rétablir l'équilibre de l'économie islandaise et poser les bases d'une reprise durable. Il leur est surtout recommandé de chercher à adhérer à la zone de l'euro et d'appliquer les mesures d'assainissement budgétaire nécessaires pour se conformer au programme du FMI.

Ce document de travail se rapporte à l'Etude économique de l'OCDE de l'Islande 2009.

(www.oecd.org/eco/surveys/Islande)

Classification JEL : E21 ; E42 ; E52 ; E62 ; H51 ; H52 ; H60

Mots clés : inflation ; volatilité, ciblage de l'inflation ; des anticipations de l'inflation ; objectif de taux de change ; crédibilité de la politique ; contrôle des mouvements de capitaux ; l'UE ; zone euro ; zone monétaire optimale ; assainissement budgétaire ; impôts ; salaires dans le secteur public ; investissement du secteur public ; cadre de la politique budgétaire ; l'efficience des dépenses sociales ; nombre d'élèves par enseignant ; soutien aux producteurs dans l'agriculture ; Islande.

\section{Copyright OECD 2009}

Application for permission to reproduce or translate all, or part of, this material should be made to: Head of Publications Service, OECD, 2 rue André-Pascal, 75775 Paris cedex 16, France. 


\section{TABLE OF CONTENTS}

Iceland: Challenging times for monetary and fiscal policies......................................................................

The limits of monetary policy in a very small open economy ……........................................................5

Icelandic monetary policy has struggled to deliver stable inflation and exchange rates..........................5

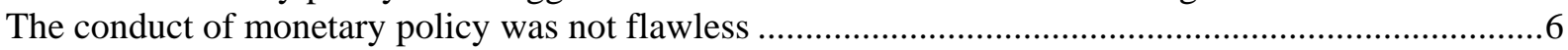

It is difficult to conduct monetary policy in a very small open economy .........................................10

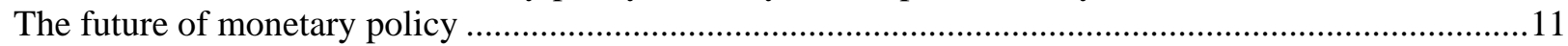

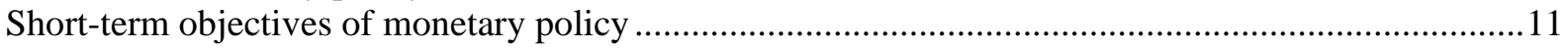

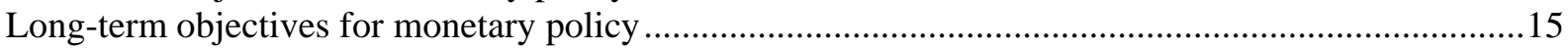

Substantial fiscal consolidation measures are urgently needed ..............................................................25

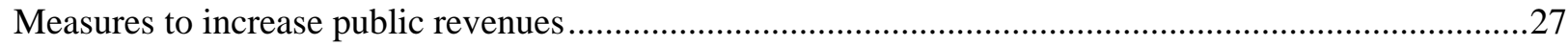

Immediately reverse the tax cuts implemented over the boom years...................................................27

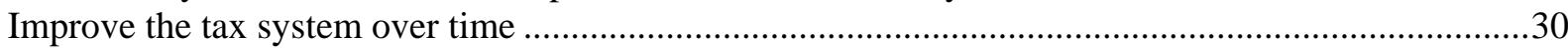

Make sure the unemployment benefit system is properly funded ..........................................................31

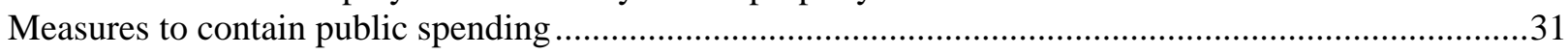

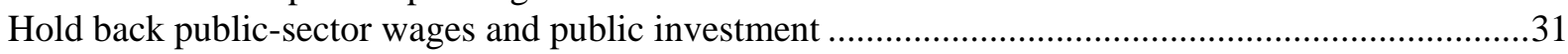

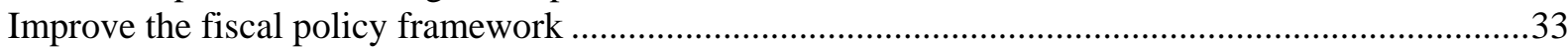

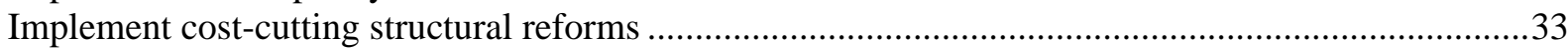

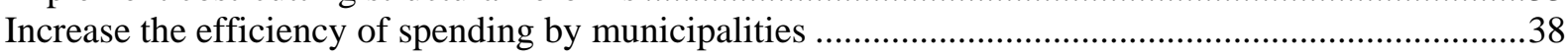

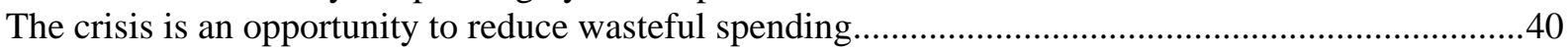

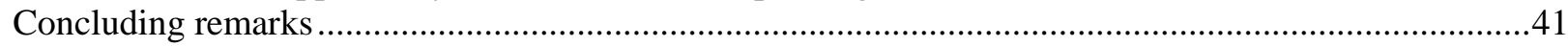

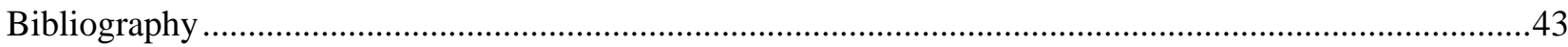

\section{Tables}

1. Correlation coefficients with euro area real GDP growth and inflation, 1997-2007 ...........................18

2 Correlation coefficients of underlying shocks between Iceland and selected countries, 1997-2007......19

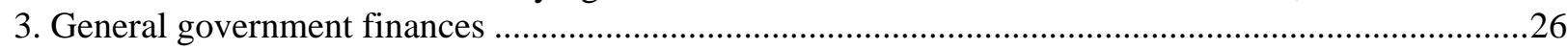

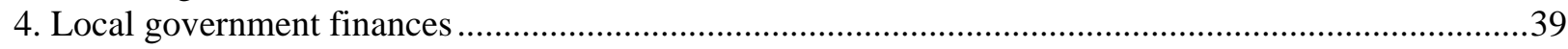

5. Agriculture: Producer support estimate ……….................................................................................40

6. Estimated savings for selected fiscal consolidation measures ..............................................................41

\section{Figures}

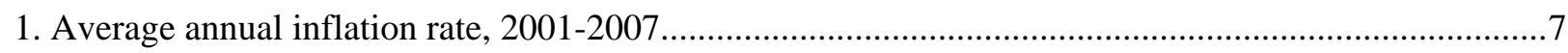

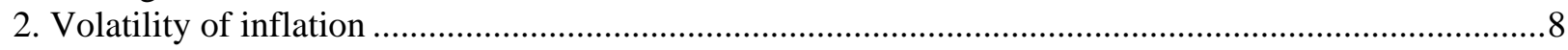

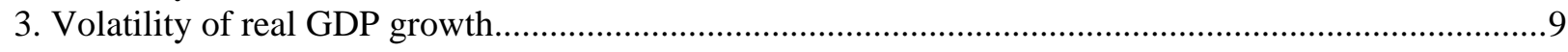

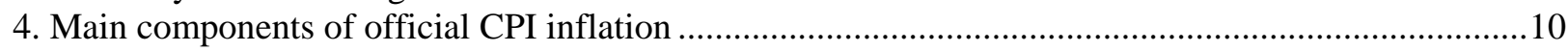

5. Aggregate demand and supply for Iceland and the euro area ............................................................19 


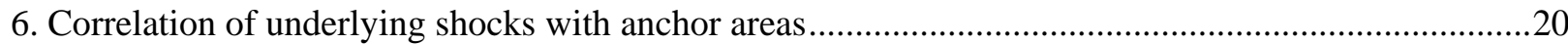

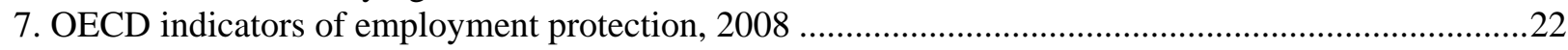

8. Real effective exchange rates in Iceland and other commodity producers ........................................25

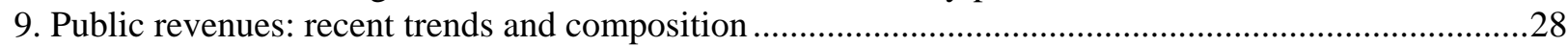

10. Personal income tax and value-added tax collected by the central government................................29

11. Public expenditures: recent trends and composition ...........................................................................32

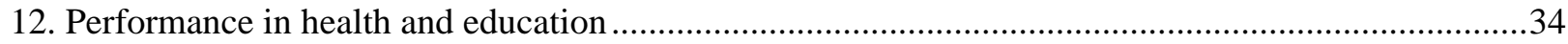

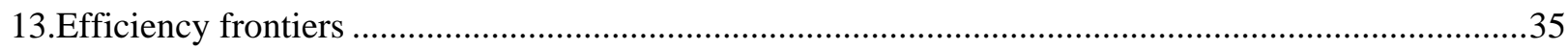

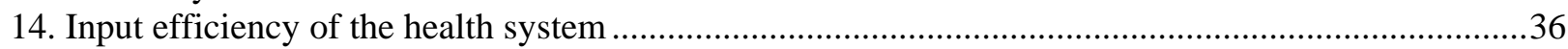

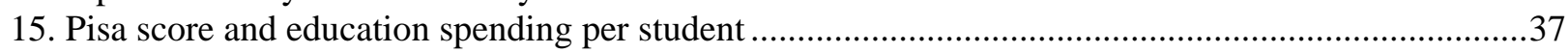

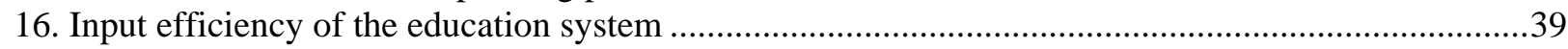

\section{Boxes}

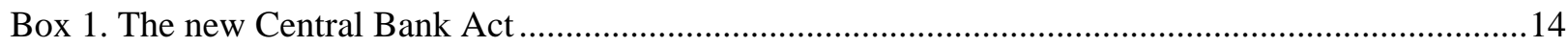

Box 2. How synchronised is Iceland with the euro area? ....................................................................18

Box 3. How loose is Employment Protection Legislation (EPL) in Iceland? ...........................................21

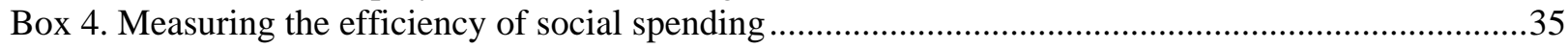

Box 5. Policy recommendations for monetary and fiscal policies............................................................42 
ECO/WKP(2009)67

\title{
Iceland: Challenging times for monetary and fiscal policies
}

\begin{abstract}
By Andrea De Michelis ${ }^{1}$
1. In the wake of the collapse of the banking sector, monetary and fiscal policy challenges have grown hugely. On the monetary front, the IMF programme, capital controls and very high interest rates have helped to stabilise the financial situation, although at a high economic cost. On the fiscal side, the wide deficit must be reduced rapidly and sustainably, and the large national debt will have to be lowered substantially. This paper looks first at monetary policy, examining the roots of unsatisfactory inflation outcomes in the past and suggesting a new orientation to take once capital controls have been lifted. The key recommendation is that, if it were to become an EU member, Iceland would be advised to seek entry into the euro area as soon as feasible, so as to reap the economic benefits. In the short term, policy credibility should be strengthened as much as possible to allow the inflation-targeting regime to be revived, consistent with the ultimate goal of euro adoption. The paper then considers the orientation of fiscal policy, which faces the prospects of high public indebtedness, double-digit public deficits and rising debt servicing costs, requiring a lengthy period of consolidation. As planned, this calls for an aggressive multi-year fiscal consolidation programme, which is also necessary in preparation for an eventual euro adoption. The challenge will be to raise taxes without unduly harming growth, and cut expenditures at the time when social needs are most acute.
\end{abstract}

\section{The limits of monetary policy in a very small open economy}

\section{Icelandic monetary policy has struggled to deliver stable inflation and exchange rates}

2. Iceland has struggled with high and volatile inflation for a very long time. At least since the early 1990s and until 2001, monetary policy was seeking to control inflation with the exchange rate serving as a nominal anchor. The increase in international capital flows that characterised financial market developments during the 1990s, however, frequently put the managed floating exchange-rate framework under considerable pressure, as the maintenance of the exchange-rate target often came at the cost of domestic stability. Indeed, growth fluctuations were pronounced and inflation was volatile. As discussed in previous OECD Surveys of Iceland, a flexible exchange rate was thought to be an important adjustment mechanism for an economy particularly vulnerable to supply-side shocks. Additional interest rate flexibility was also considered to be helpful to this regard. Furthermore, the maintenance of the exchange rate peg was costly at times, and became increasingly difficult. These were the main reasons which prompted Iceland to adopt inflation targeting in 2001.

1. The paper was originally produced for the 2009 OECD Economic Survey of Iceland, published in August 2009 under the authority of Economic and Development Review Committee of the OECD. I would like to thank, without implicating, Andrew Dean, Robert Ford, Patrick Lenain and David Carey, for valuable comments and/or discussions. I am also grateful to Roselyne Jamin for technical assistance and to Pascal Halim for secretarial assistance. 
3. In March 2001, Iceland allowed its currency to float freely and switched to an inflation-targeting framework (Central Bank of Iceland, 2001). The move was inspired by the successful experience of other countries, including some also subject to external shocks and to exchange rate pressures. It was thought that the announcement of an explicit inflation target and the adoption of state-of-the-art practices, such as the publication of a quarterly inflation forecast, would provide the necessary credibility to improve the stability to the Icelandic economy. The inflation-targeting framework was strengthened over time. In particular, the communication strategy adopted by the Central Bank of Iceland (CBI) at the beginning of 2007 was nearly state of the art. Following the lead of the Reserve Bank of New Zealand, the Norges Bank of Norway and the Riksbank of Sweden, the CBI began publishing its conditional expectation of the path of interest rates. Disclosing the policy forecasts enhanced transparency and was thought to make it easier for monetary policy to influence interest rates at the long end of the yield curve, which are primarily driven by expectations on how the policy rate will evolve over time. Similarly, the CBI adopted the practice of discussing alternative macroeconomic scenarios, with the aim of clarifying the reaction function of monetary policy, and thus making it more predictable and effective.

\section{The conduct of monetary policy was not flawless}

4. One of the potential advantages of the inflation-targeting framework over a discretionary approach to monetary policy is that it should strengthen the expectation channel of the monetary policy transmission mechanism. A pre-condition for this mechanism to work is the high credibility of the monetary authorities, which, in turn, requires a perception that the central bank will not be influenced by political factors. However, studies carried out before the regime switch showed that Iceland ranked near the bottom amongst industrialised nations in terms of central bank independence (Fry et al., 2000; Pétursson, 2000). Iceland scored particularly low on the emphasis given to price stability in its charter. Creating a more independent central bank was therefore crucial to make inflation targeting operative. However, the appointment of a former Prime Minister as the head of the reformed CBI in 2005 and the habit of the members of government of openly commenting on the interest rate decisions sent the opposite message.

5. Another condition for the expectation channel to work is that the monetary authorities act, and be perceived to act, decisively to attain the inflation target. However, inflation has exceeded the official target from 2004 onwards, and over the 2001-2007 period, inflation averaged nearly twice the CBI's target. Even before the spike in prices associated with the sharp devaluation of the króna late in 2008, Iceland's inflation performance did not compare favourably with those of other inflation-targeting countries and most other OECD-member countries (Figure 1). A notable exception is the group of Eastern European countries, a number of which have since joined or sought entry in the euro area. 
Figure 1. Average annual inflation rate, 2001-2007

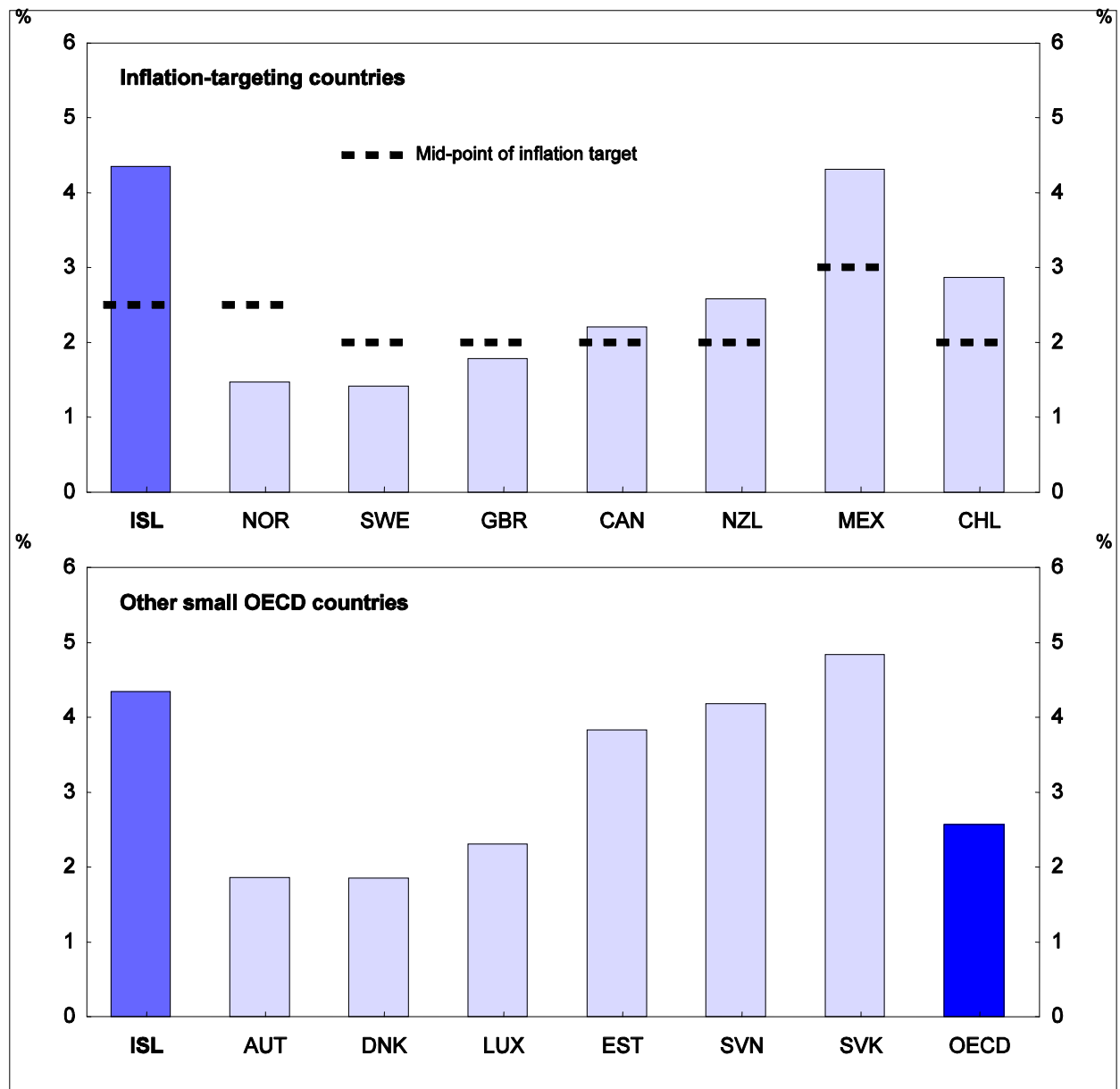

Source: OECD, Main Economic Indicators.

6. In terms of inflation volatility, the performance of Iceland appears even worse (Figure 2). Inflation volatility was mostly due to a high degree of nominal and real exchange rate volatility. This is in contrast with the experiences of other open economies (Bravo-Ortega and di Giovanni, 2006) and other small economies (Devereux and Lane, 2003; and Pétursson, 2008), suggesting that the authorities were too willing to tolerate large exchange-rate fluctuations. The combination of high and volatile inflation made real activity less stable (Figure 3). Arguably, it also lowered the economy's productive potential, by making it more difficult for households and firms to distinguish between changes in relative and in overall prices and thereby reducing the efficiency with which Iceland's limited resources were allocated. 
Figure 2. Volatility of inflation ${ }^{1}$

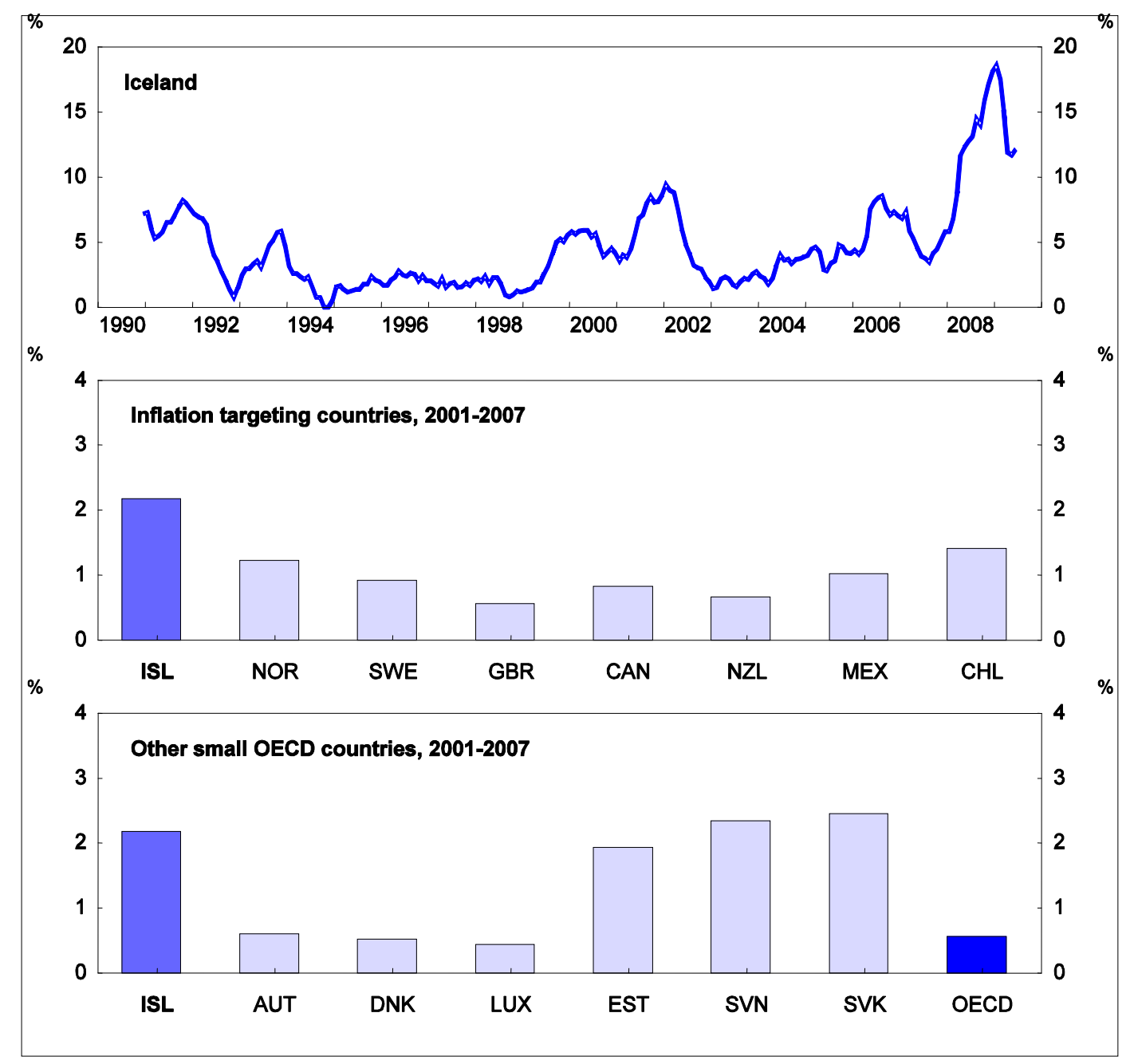

1. Measured as the standard deviation of year-on-year percentage change of the monthly consumer price index. Source: OECD, Main Economic Indicators. 
Figure 3. Volatility of real GDP growth ${ }^{1}$

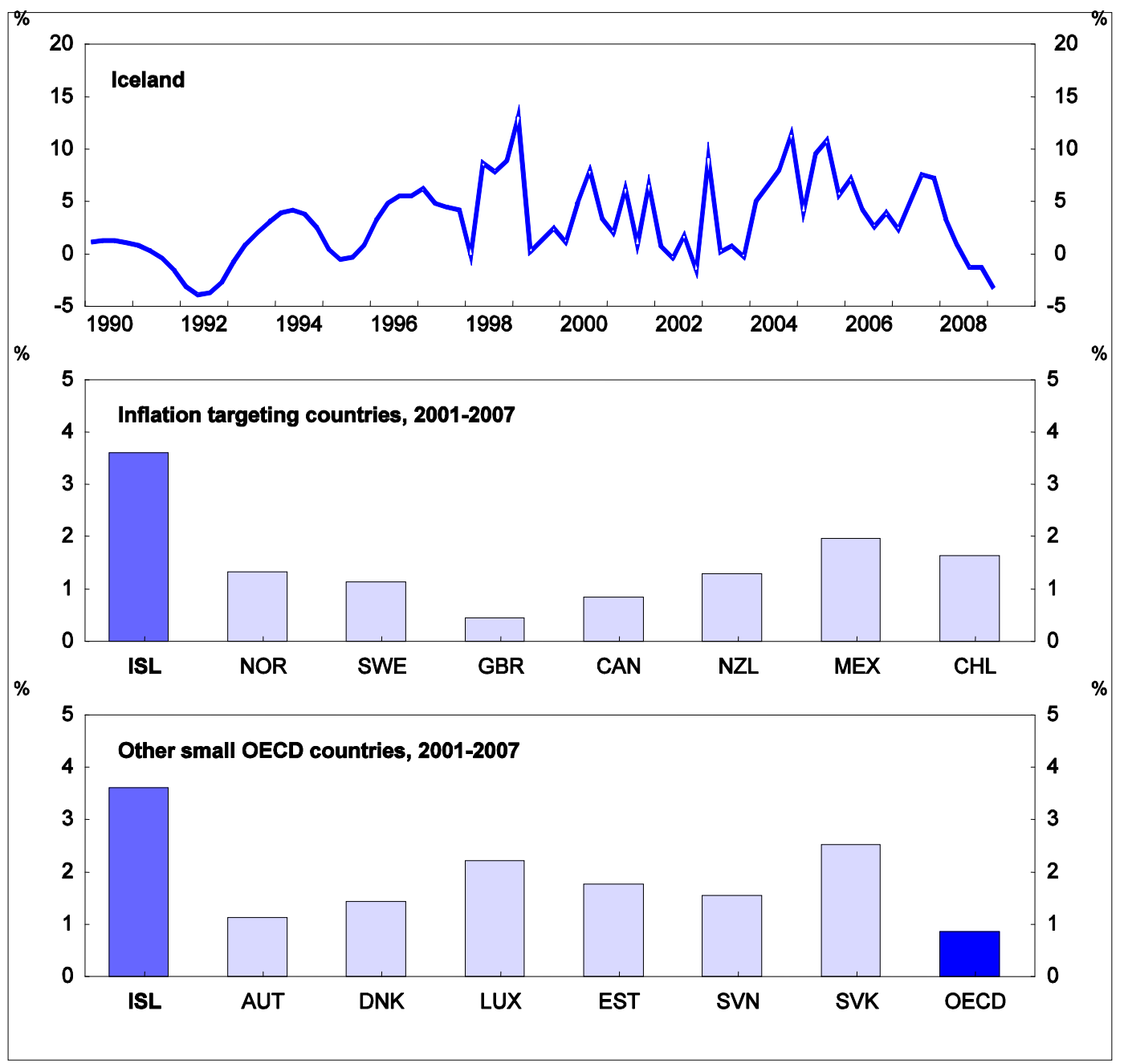

1. Measured as the standard deviation of the year-on-year percentage change in real GDP.

Source: OECD, Analytical database.

7. While the unsatisfactory inflation performance was partly due to unavoidable errors in forecasting, both the OECD and the IMF noted that the conduct of monetary policy showed a tendency to respond too timidly to the worsening inflation outlook (OECD, 2006; IMF, 2007; OECD, 2008). The interest-rate decision taken in December 2005 provides a case in point. At that time, the CBI was projecting two-year-ahead inflation to be just below $4 \%$, the threshold above which the CBI is required to prepare a detailed report explaining the reasons for the deviations from the target. Despite the elevated inflationary pressures and an overheated economy, however, the policy rate was increased by only 0.25 percentage points. As concluded in the 2006 Survey, "the Central Bank's announcements do not seem to be credible. The public does not seem to believe its statement that it will do whatever is necessary to hit the target."

8. Nevertheless, as discussed in Carey (2009), the relative inflation performance of Iceland improves significantly when compared using an internationally comparable measure, such as the harmonised index of consumer prices (HICP). The main difference between the HICP and Iceland's official inflation measure is that the latter includes the price of owner-occupied housing. Statistics Iceland computes such a component as an annuity where the principal is the market value of the property and the 
discount rate a relatively short moving average of recent mortgage rates. The housing price index is thus a function of actual housing prices and current mortgage rates. Accordingly, a pronounced increase in house prices, as was experienced by Iceland until mid-2007, boosts the official inflation rate. Indeed, the housing component accounted for more than half of the price increases recorded over the boom years (Figure 4). By contrast, measured according to the HIPC, the average annual rate of inflation over the 2001-2007 period was $2.9 \%$, not far from the average rate for the euro area over the same period (2.2\%). However, the fact remains that the official measure of inflation was repeatedly well above the official target, which undermined credibility.

\section{Figure 4. Main components of official CPI inflation}

12-month rate

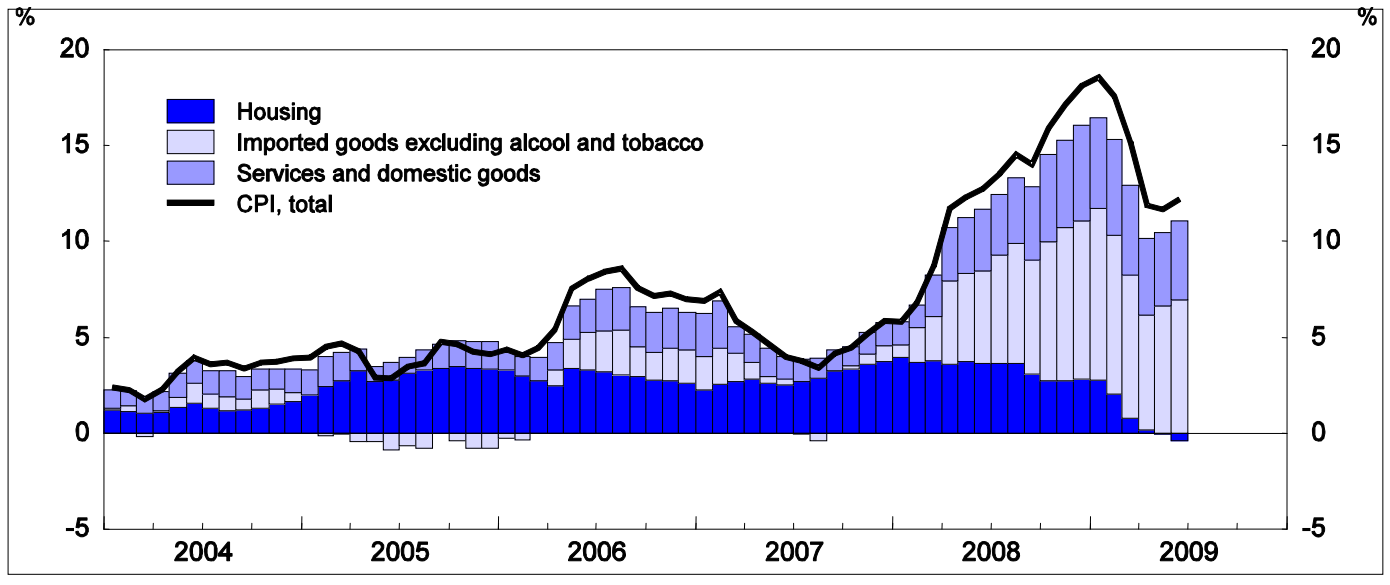

Source: Statistics Iceland and Central Bank of Iceland.

9. In short, the new regime failed to establish a solid reputation for Iceland as an inflation-adverse country, and therefore did not succeed in stabilising the economy which is the primary task of monetary policy. The lack of adequate credibility is clearly reflected in inflation expectations, which remained poorly anchored according to all available measures, as shown in Carey (2009) (Figure 1.21). Mishkin (2008) argues that the inflation-fighting credibility of the central bank exerts considerable influence on the degree of exchange-rate pass-through to consumer prices, which, not surprisingly, has remained particularly elevated in Iceland (Pétursson, 2008).

\section{It is difficult to conduct monetary policy in a very small open economy}

10. While the Iceland's inflation problems were surely related to the conduct of monetary policy and lack of credibility, independent monetary policy may not be an effective stabilisation tool in a very small open economy, such as Iceland. First, as noted, the degree of exchange-rate pass-through to consumer prices is particularly high, which makes the exchange rate a very important channel for the transmission for monetary policy to real activity. While this means that monetary policy is not impotent, it also implies that a strict stance squeezes the export sector while benefitting the domestic sectors and consumers through lower import prices. Perceptions of hardship in the export sector and more generally the uneven burden of monetary policy inevitably turn out to be a source of strong criticism of the monetary authority. Several commentators have argued that such political-economy concerns limit the room for monetary policy manoeuvre and therefore enhance the case for fiscal policy playing a more prominent short-run stabilisation role (Schmidt-Hebbel, 2006). However, in Iceland, fiscal policy did not always play this role. While substantial fiscal surpluses were accumulated and net debt was nearly eliminated, fiscal policy, especially with the benefit of hindsight, did not always adequately counter the overheating of the economy during the boom period. Looking forward, fiscal policy will need to be devoted for some years to restoring a sustainable position in the wake of the collapse of the banking sector. 
11. Second, as could not be better exemplified than by the unfolding of events in Iceland during the course of 2008, monetary policy, defined as the setting of the short-term policy interest rate, is a hopeless tool to stabilise a very small open economy facing a mismanaged financial liberalisation process and powerful developments in global capital markets (Elíasson and Pétursson, 2009). As examined in Carey (2009), the competition between the government-controlled Housing Financing Fund (HFF) and the newly privatised banks led to a race-to-the-bottom in the mortgage market: real interest rates fell, credit standard deteriorated, and foreign-currency loans became widespread. This fuelled a housing bubble, which began deflating in 2007 and then burst as Iceland's financial system collapsed. The mismanagement of the domestic financial system also contributed to a disconnection between short- and long-term interest rates. In other words, a potentially important mechanism for the transmission of monetary policy, the mortgage-rate channel, was broken. Interest rates in Iceland were obviously also affected by the developments in the global financial market. The "savings glut" and a search-for-yield fed a massive carry trade, which left unsupervised by the domestic authorities, fuelled up an already overheated economy. Carry-trade investors arguably exploited the efforts of the CBI to achieve its inflation target by increasing the influx of capital as inflationary pressures mounted, reassured that short-term interest rates would increase, or at least remain high, for the foreseeable future (for a critical assessment of how inflation targeting can transform bad news on inflation into good news for the currency, see Clarida and Waldman, 2008). Finally, when the global financial markets seized up in the aftermath of the failure of Lehman Brothers and the domestic banking sector collapsed, there was not much the CBI could do to prevent the sharp depreciation of the króna, the jump in prices and the plunge of economic activity.

12. It is important to draw some lessons from Iceland's experience over the past decade. First, successful implementation of an independent monetary policy is bound to result in serious pressures being placed on the export sector. Second, fiscal policy will also have to play a prominent role as a short-term stabilisation tool, although, over the near term, the fiscal policy stance will have to be strongly pro-cyclical in order to adequately confront the challenges posed by financial crisis and the collapse of the economy. And above all, macro- and micro-prudential supervision of the financial system will need to be greatly improved by taking decisive measures such as those recommended at the end of Carey (2009). Without that, monetary policy will continue facing an impossible task. A small open economy with its own currency and a fragile financial sector is prone to experience further booms and busts, no matter what the stance of monetary policy will be. The crisis shows that it will also be crucial that the global financial system becomes better regulated and more resilient, an issue that is, however, outside of the control of Icelandic policymakers.

\section{The future of monetary policy}

13. This section considers the requirements for Iceland's monetary policy framework. For the time being, policy will be governed by the IMF programme and the overriding immediate need to stabilise the financial market. Even so, the authorities can take action to rebuild monetary policy credibility. For the longer term, this section argues that Iceland should adopt the euro, and discusses the policy requirements and difficulties of such a project. Since there will be a period of transition between the end of the current regime of capital controls and euro adoption, the inflation targeting-framework that has been de facto suspended should be resuscitated, although the success of this will depend critically on rebuilding credibility and ensuring a stable domestic financial system.

\section{Short-term objectives of monetary policy}

Restrictions on capital movements should be gradually removed as soon as feasible

14. The collapse of the banking sector led to a recalibration of the monetary policy objectives. The effective exchange rate plunged $40 \%$ in early October 2008 with respect to its level at the beginning of the year. The domestic authorities and the IMF agreed that stabilising the króna was a fundamental element of 
the programme for economic recovery. Consequently, exchange controls on capital movements were introduced to prevent a disorderly outflow of capital held by foreigners (about 40-50\% of 2009 GDP). According to CBI estimates, as of April 2009, non-resident holdings included ISK 204 billion (14\% of 2009 GDP) in domestic deposits, ISK 60 billion (4\% of 2009 GDP) in CBI certificate of deposits, ISK 205 billion (14\% of 2009 GDP) in nominal bonds, and ISK 162 billion (11\% of 2009 GDP) in inflation-indexed bonds (Central Bank of Iceland, 2009). Preliminary estimates by the CBI also indicate that roughly $40 \%$ (approximately ISK 250 billion) of the total holdings are held by so-called "impatient" investors, i.e. investors that would "rush to exit" if they could (Central Bank of Iceland, 2009). If a disorderly outflow occurred, the exchange rate would fall sharply, undermining policy credibility and perhaps driving many firms and some households into bankruptcy owing to their un-hedged foreign exchange positions. A substantial share of the foreign currency borrowing appears to have been done by the Icelandic investment firms to finance their foreign equity asset purchases. About $50 \%$ of corporate borrowers with foreign currency denominated debt do not have foreign currency earnings. In addition, some $20 \%$ of households have foreign-exchange denominated mortgages. However, little is known, for both firms and households, about the extent of un-hedged positions. In preparation for the progressive removal of capital controls, the authorities should obtain information on the extent of outstanding foreign currency exposures, which requires information on both foreign currency loans and sources of revenue, so as to be able to properly assess the risks arising from a possible further depreciation of the exchange rate following the removal of exchange controls.

15. The capital controls also have protected the domestic banking system from the risk of large withdrawal of deposits by residents wishing to transfer their assets abroad. As well, by disallowing investments abroad, the controls have effectively forced domestic creditors to lend to domestic borrowers. Consequently, the market interest rates - at least for those borrowers who continued to have access to credit - have not increased as much as would have been warranted by the higher risk perceptions. Over the course of 2008, Iceland's sovereign debt was downgraded to nearly speculative grade by the major credit rating agencies. Nevertheless, the Housing Financing Fund - the government-controlled mortgage lender has been able to raise funds at rates which, in real terms, have not been too far off, on average, from those prevailing before the burst of the crisis.

16. The authorities intend to gradually remove the capital controls within the two-year life of the IMF programme. Above all, the removal of the restrictions is a necessary step to restore Iceland's credibility. However, they should be lifted only when a medium-term fiscal consolidation plan is well underway, the banking sector has been put back on its feet, and there are adequate international reserves. To guard against the risk that the foreign investors might move their króna-denominated assets out of Iceland, the CBI and the IMF envisage liberalising the capital account initially only for new flows. Controls would remain on non-resident króna holdings until the position improved enough to remove these controls as well. This solution is technically feasible, but very complicated. With this in mind, the authorities should remove restrictions on new capital flows only when it is safe to do so, and, in any case, not before the banking sector has been stabilised. Partial removal of capital controls could also facilitate the complete removal of the controls over the existing non-resident króna holdings without causing further major disruption, since even partial removal would, if new foreign investment were successfully forthcoming as envisaged, generate competitive returns in Iceland. In these circumstances, the value of the króna might no longer be seen as a one-way bet, particularly given that the real exchange rate is currently well below its long-term average. Accordingly, the government should remove the capital controls that block non-resident króna holdings as soon as feasible.

\section{Stabilising the króna while the conditions for removing the capital controls are put in place}

17. A tight monetary policy stance is needed to support the external value of the króna, since capital controls do not work perfectly. This means that, de facto, monetary policy has, at least temporarily, shifted from an inflation-target to an exchange-rate target. In the words of the Central Bank's Governor 
Oygard (2009): "Current monetary policy is guided by the interim objective of stabilising the exchange rate, while the inflation target remains the long-term goal." In any case, it should be noted that under the current circumstances exchange rate stability is, perhaps more than ever, an important factor in re-establishing price stability. Given the weak state of the Icelandic economy and the economic distortions accompanying capital controls, both are currently indispensable elements of a strategy to support a sustainable recovery.

18. Despite this aggressive and unorthodox policy response, the króna has been quite volatile in 2009, and the effective exchange rate has depreciated a further $12 \%$ by early July, relative to the beginning of October 2008. The 12-month inflation rate, after peaking at $18.6 \%$ in January, has decelerated sharply, dropping to $12.2 \%$ in June. As inflationary pressures began to subside, some lowering of interest rates was justified, although the extent of the decline in real rates has not been large. At the same time, however, much of the decline in inflation can be imputed to base effects in the housing price component (Figure 4) and underlying inflation has remained well above the (long-term) inflation target of 21/2 per cent. In any case, until the conditions for removing the capital controls are put in place, monetary policy should continue to focus on stabilising the króna, which reduces the room for further interest rate cuts.

\section{Rebuilding policy credibility}

19. It is essential that the CBI improve its credibility. To this end, the Central Bank should make clear that it stands ready to do what is necessary to achieve its objectives. For instance, the CBI should take full responsibility for the tight monetary policy stance, explaining clearly that this is needed to support the capital controls and prevent a catastrophic outflow of capital. By taking this sort of ownership, it can demonstrate that it understands that tough policy choices will be needed in the years ahead and that it is prepared to implement them. By the same token, politicians and other government officials should refrain from publicly commenting on monetary policy implementation, as distinct from policy goals, which are properly in the political sphere.

20. The amendments to the Act on the CBI introduced in February 2009 are a welcome step for strengthening credibility (Box 1). The establishment of a Monetary Policy Committee (MPC) and new qualification requirements for the governor and deputy governor should improve the governance structure of the Central Bank. Publication of the minutes of policy rate meetings will improve transparency and thus the effectiveness of monetary policy. It is equally important that coherent actions follow these organisational changes. For example, leading political figures should not be nominated as members of the MPC. A more independent central bank would also need to become more accountable. The Act's requirement that the MPC report to the Parliament on its work twice a year is welcome and consistent with practice in several OECD countries. The new government is also planning to transfer the supervision over the CBI from the Prime Minister's office to a new Ministry of Economic Affairs, which will also be responsible for the Financial Supervisory Authority (FME), Statistics Iceland and economic policy. This arrangement should improve coordination of monetary policy and financial supervision. 


\section{Box 1. The new Central Bank Act}

One of the main legislative initiatives by the Icelandic interim government in the period ahead of the May 2009 elections was to amend the Central Bank Act. The new Act made several changes to the administrative structure of the $\mathrm{CBI}$. The changes were intended to ensure that the Bank has a qualified senior management, thereby ensuring professional and objective decision-making concerning the application of the Bank's monetary policy control mechanisms. Two principal substantive changes were introduced by the Act.

- $\quad$ First, it abolished the Board of Governors and it replaced it with a single, professional Governor who is in charge of the Bank's operations. The procedure for appointing the Governor and the Deputy Governor of the Central Bank was also modified. The new procedure requires public advertisement of the positions and minimum professional qualifications. The term of both positions is five years and the same person can only be appointed Governor or Deputy Governor twice.

- $\quad$ Second, the Act established a Monetary Policy Committee (MPC) within the Bank, with the task of taking decisions on the application of the Bank's monetary policy control mechanisms. The MPC is comprised of the Governor, the Deputy Governor, one of the Bank's executives responsible for formulating or implementing monetary policy and two outside experts in the field of economic and monetary policy appointed by the Prime Minister for a five-year term.

One of the stated goals of the new Act was to render the Central Bank more independent from political considerations, which often appeared to have been a major factor in appointments to the Board of Governors. The qualifications stipulated for appointment as Governor and as Deputy Governor of the CBI, and the legal obligation to advertise applications for the position, were intended to preclude the possibility of such considerations taking precedence in these appointments.

The Act also stipulated that minutes of the meeting of the MPC have to be made public, and in accordance with the Act the MPC has decided to publish the minutes of its policy rate meetings two weeks after each decision. Furthermore, the MPC was required report to the Parliament on its work twice each year.

21. Another measure that the government can take to improve the credibility of the CBI would be to change the targeted inflation measure. As mentioned above, the official CPI includes a component for owner-occupied housing services which is closely tied to market housing prices. This is problematic for at least two reasons. First, research by top academics indicates that central banks should target measures of inflation which put more weight on prices which move sluggishly and exclude asset prices such as housing, but which can take account of the imputed rents from these assets (e.g. Aoki, 2001; Woodford, 2003). Second, Icelandic mortgages are typically issued at fixed real rates for terms of up to 40 years, and therefore they are only slightly affected by the monetary policy stance. In other words, the CBI has been targeting a price index which not only is sub-optimal according to leading academics but also includes a component over which its policy rate has a very limited influence. Not surprisingly, no other central bank in any OECD-member country targets an inflation measure which is affected by market housing prices to the extent witnessed in Iceland's official CPI.

22. It could be argued that the measure adopted by the CBI may be preferable to those adopted elsewhere, since it automatically incorporates "leaning against the wind" considerations in an inflationtargeting framework. However, as the recent debacle has revealed, the approach of targeting an index very sensitive to housing prices did not work: it just made the inflation goal more difficult to achieve, and thus less credible. This recommendation does not mean in any way that monetary policy should ignore price developments of housing and other assets. To the contrary, as has been clearly demonstrated by unfolding events in Iceland and the rest of the world since mid-2007, monetary authorities ought to pay much more attention to such prices (Yellen, 2009). 
23. One way to properly take into account the price of the service flow of owner-occupied housing would be to switch from a user's cost of capital approach to a rental equivalence approach, as practiced in the United States and in other OECD countries (Christensen et al., 2005). However, that solution does not seem a viable solution in Iceland since, once social housing is excluded; the rental market is extremely thin. For the time being, the only readily available solution would be to adopt the HICP as the relevant measure of inflation, since this measure is not affected by housing prices. (Eurostat is in the process of introducing an owner-occupied housing component into its price basket based on building materials and replacement costs, which should improve the HICP one implemented). The HICP also has the advantage of being internationally comparable and it is also the measure of inflation that would have to be targeted for entry to the euro area. Last but not least, it would be preferable to switch the target at a time when HICP inflation is running above CPI inflation, as is currently the case, since this would not risk undermining CBI credibility. For this reason, the authorities should take action without delay to adopt the HICP as the targeted inflation measure.

\section{Long-term objectives for monetary policy}

Drawing lessons from the past

24. Once capital controls are removed, which should be done as soon feasible, the authorities will have to implement an alternative monetary policy framework. While a number of measures have been taken and could be taken to improve the operation of monetary policy, the history of both a managed floating exchange rate and inflation targeting suggests that independent monetary policy may not be a good option for Iceland in the longer term.

25. Another concern is that carry traders may one day return, complicating the implementation of monetary policy. Also with this in mind, some observers have suggested that access to a global reserve currency is the only viable solution in today's globalised financial markets.

26. Unilateral adoption of a foreign currency, such as the euro, as has at times been advocated in some policy circles, does not appear to be a viable solution in Iceland. The conversion to euros and the loss of seignoirage would be costly for public finances. The domestic banking sector would also lose access to a reliable discount window, and thus would become prone to bank runs. And, perhaps above all, the transfer of national sovereignty to the European Central Bank (ECB) without political legitimacy would be unlikely to survive over the long run (Buiter, 2000). Last but not least, the ECB has clearly stated its opposition against any unilateral "euroisation" of the Icelandic economy and the OECD recommended against it in the 2008 Survey.

\section{The case for joining the euro area}

27. Seeking to join a monetary union - for practical purposes, the euro area - appears to be the only durable solution. The process towards euro-area membership is going to be complicated and will take some time. During the transition period, both monetary and fiscal policy will have to be subordinated to meeting the criteria for euro-area entry. In this respect, however, Iceland is relatively well placed. The fiscal consolidation the authorities have already committed to (see below) and the existing inflation-targeting framework are both consistent with the ultimate goal of euro adoption. Moreover, Iceland is already a member of the European Economic Area (EEA) and, as such, many of the pre-conditions for EU membership - a necessary step along the road toward the euro - are already in place. A number of other countries have gone through the application process in the past, with some also making intelligent use of the membership goal to implement important, but otherwise politically difficult, structural reforms. The process will also serve to give political legitimacy to a decision which, it should not be forgotten, involves relinquishing national sovereignty on certain matters, such a monetary policy, to a super-national entity. And political legitimacy would also come from having a voice in the EU's and the ECB's decision-making processes, which would not be the case under unilateral "euroisation." 
28. The harmonisation of Iceland's agriculture and fisheries policies to those prevailing in the European Union represents the main challenge for EU membership negotiations. Liberalising trade in agricultural goods and, more importantly, reaching an agreement over the management and exploitation of Iceland's fisheries are both likely to entail some costs. Iceland's fishing industry is an important economic sector - accounting, in recent years, for 7\% of GDP and over 30\% of merchandise exports - and is part of the country's national identity. In addition, its fisheries policy is often regarded as a model to follow; while, by contrast, the EU common fisheries policy (CFP) has produced unsustainable fish stocks and a weak fisheries sector. A 1997 OECD assessment on the fisheries management systems of its member countries concluded that "the [EU] fisheries sector is characterised by overfishing, lower production and income than could have been obtained and the existence of a latent sectoral crisis" (OECD, 1997). In April 2009, the European Commission published a consultative green paper on the CFP which finds that $88 \%$ of the EU's stocks are overfished and that in several EU countries the cost to public budgets of subsidising fishermen "exceeds the total value of the catches" (EC, 2009). The green paper, which is part of a plan aimed at reforming the CFP by 2013, also suggests that the EU should learn from countries, such as Iceland, where fisheries are managed based on individual transferable quotas, i.e. fishermen hold individual rights that can be sold or leased to others (albeit with some limitations). In sum, if Iceland applies for EU membership, negotiations over this contentious issue would likely be difficult, but there seems to be scope for both improving the CFP and finding an acceptable compromise over Iceland's fisheries.

29. Assuming that a compromise on fisheries can be reached and that the EU application is successful, membership in the European Economic and Monetary Union (EMU) would entail significant benefits. Iceland would finally have a stability-oriented monetary policy and share the seignorage revenues of the Eurosystem, while its banks would gain full access to the reliable discount window of the ECB. Especially for Iceland, with its history of high and volatile inflation, euro area membership appears the most logical strategy to stabilise the economy. Moreover, the CBI credibility could immediately gain from a firm political decision to quickly join the EMU. In the past, at least since the times of the European Monetary System (EMS), other inflation prone-countries, such as Italy, Spain, Portugal and Greece, have found that participation in cross-country monetary arrangements has served as an effective disciplinary device and facilitated the conduct of monetary policy (Giavazzi and Pagano, 1988).

30. Entry to the euro area would also eliminate the exchange rate risk and open access to the large euro capital market, which should lower Iceland's real interest rates towards euro area levels. This would reduce the government's debt servicing costs - which, as discussed later in this paper, will be very helpful given the dire situation of public finances - as well as ease balance sheet adjustment for the private sector. Lower interest rates would also stimulate capital investment, which would increase labour productivity. While it is difficult to quantify by how much the Iceland's real interest rates might fall as a result of euro area membership, the experiences of past applicant suggest that the effects are large. For instance, a recent study of the Slovak Republic's successful bid finds that the exchange rate premium, which during 2006 still amounted to around 1\%, fell to zero immediately after entry was approved (Huefner and Koske, 2008). At the same time, financial supervision, as recommended in Carey (2009), should be strengthened to ensure that low interest rates do not spur another unsustainable credit boom.

31. Another advantage of entry to the euro area is that sharing of a common currency would reinforce trade linkages with other euro-area economies. A common currency among partner countries is seen as "a much more serious and durable commitment" (McCallum, 1995). Amongst others, it rules out future competitive devaluations, and facilitates foreign direct investment and the building of long-term relationships. In a seminal paper, Rose (2000) finds a large positive effect of a currency union on international trade. By using a gravity model on a panel covering 186 countries during 1970-90, Rose finds that countries sharing the same currency trade three times as much as they would with different currencies. Frankel and Rose (2000) extend the framework of Rose (2000) and use a panel covering 200 countries plus 
dependencies. Their main findings are that: currency union more than triples trade among partner countries. Rose and Van Wincoop (2001) find instead that euro-area entry would spur trade by more than 50\%, a considerably smaller estimate. Research by Melitz (2001) and Persson (2001) argues for even lower estimates. The minimum point estimate from Persson is a $13 \%$ increase in trade from currency unification with a preferred estimate of around 40\%. Melitz's estimates are higher. Applying the gravity trade model approach to Iceland, Breedon and Pétursson (2005) find that Iceland's trade could increase by about $60 \%$ and that the trade-to-GDP ratio could rise by 12 percentage points should Iceland join the European Union and EMU. More recent research by Flam et al. (2008) - a comprehensive report on the euro area aimed at assessing whether Denmark, Sweden and the United Kingdom should join the EMU confirms that euro-area entry has boosted trade between members of the currency union and also finds that the effect has increased over time. According to their calculations, trade within the euro area is $24 \%$ higher on average after 1999 than in the preceding years, whereas the trade between the euro area and outside countries has risen by only half of that, or $2 \%$. Other research shows that that the elimination of exchange rate volatility - which has been especially pronounced in Iceland - has fostered product differentiation in European trade. For instance, Fontagné and Freudenberg (1999) apply a different methodology than the gravity models and find that after entry in a monetary union intra-industry trade occurs more in horizontally differentiated goods (two-way trade in varieties) than in vertically differentiated goods (two-way trade in qualities). In sum, while there are different views concerning the size of the possible trade gains following monetary unification, the benefits for Iceland would most likely be considerable.

32. Euro-area entry also entails some drawbacks. Above all, monetary conditions will not always be suited to the national circumstance and Iceland would lose the flexibility to use the exchange rate to adjust to idiosyncratic shocks. Exchange rate flexibility has been very helpful in the current episode because it has facilitated some beneficial cuts in real wages. Studies of the synchronisation of the Icelandic business cycle with that of the euro area yield mixed results. This paper contributes to this literature by investigating how synchronised the Icelandic and euro-area business cycles have been during the past decade (Box 2). The main result of this analysis is that country-specific shocks tend to prevail in Iceland. At the same time, the predominance of asymmetric shocks does not seem to be too different than in some current EMU members (e.g. Portugal and Slovak Republic). Furthermore, on the same measure, there seems to be no better candidate with which to form a monetary union (with the exception of Sweden, which, at least for the time being, does not seem to be interested). 


\section{Box 2. How synchronised is Iceland with the euro area?}

The optimal currency area (OCA) literature emphasizes synchronisation of economic shocks as one of the main conditions for countries to benefit from monetary integration. This box employs standard empirical methods to shed some light on this issue based on the work carried out by the Secretariat in the context of the 2009 Survey of Estonia (OECD, 2009a; for a more complete account, see Brixiova et al., 2009). Two main features are examined: first, the structure of the economy; and second, the economy's underlying shocks.

\section{Structural similarity and correlation of economic activity between Iceland and the euro area}

The likelihood of synchronisation of shocks and the business cycles should increase with greater structural similarity of production. Over the 1997-2007 period, the correlation of Iceland's real GDP growth with the euro area has been very low, especially relative to the core countries. On this measure, however, some more recent EU member countries do not seem any better (Table 1). Correlation of Iceland's and euro-area HICP inflation has been low but not so much, especially when compared with those of other countries at the periphery. Another indication that the structure of Iceland's economy differs significantly from that in the euro area is the very low share of intra-industry trade in Iceland. Given that Iceland's exports are concentrated in aluminium and fish, the last observation should not be surprising. In any case, according to these measures, it appears that shocks and the business cycles of Iceland and the euro area are only loosely synchronised.

Table 1. Correlation coefficients with euro area real GDP growth and inflation, 1997-2007

\begin{tabular}{lcc}
\hline & Real GDP growth & Inflation \\
\cline { 2 - 3 } ISL & 0.05 & 0.38 \\
DEU & 0.92 & 0.76 \\
FRA & 0.89 & 0.92 \\
NLD & 0.79 & 0.29 \\
FIN & 0.79 & 0.23 \\
IRL & 0.51 & 0.43 \\
GRC & -0.05 & 0.18 \\
SVK & -0.27 & -0.24 \\
SVN $^{1}$ & 0.53 & -0.12 \\
\hline
\end{tabular}

Note: 1998-2007 for HICP inflation.

\section{The symmetry of shocks between Iceland and the euro area}

Despite the fact that the structure of Iceland's economy differs from that of the euro area, it is possible that the aggregate shocks influencing the two economies may be fairly similar. A standard aggregate-demand aggregatesupply model, consisting of output growth and changes in inflation, is utilised to recover the underlying demand and supply shocks in Iceland and to determine their correlations with those of the euro area and a control group.* Output is measured as real GDP, while inflation as the quarterly percentage changes in the HICP. (As discussed earlier in this paper, Iceland's official CPI is not comparable to the euro-area HICP.) Following the methodology proposed by Bayoumi and Eichengreen (1992), a 2x2 structural VAR model is indentified posing four simple restrictions. Two of these restrictions are simple normalizations of the variance of the shocks; a third restriction comes from assuming that demand and supply shocks are orthogonal; and the final restriction, is that demand shocks have only temporary effects on output. These restrictions also imply that demand shocks will raise prices in both the short and the long run, while supply shocks will lower prices.

The results indicate that the correlation of the demand shocks between Iceland and the euro area have been positive but low, while supply shocks appear to have been uncorrelated (Figure 5 and Table 2). For robustness, the VAR model is estimated for longer and shorter time periods but the qualitative results do not change. These findings confirm the presumption that, especially with regard to supply shocks, the business cycle in Iceland differs from that in the euro area. 


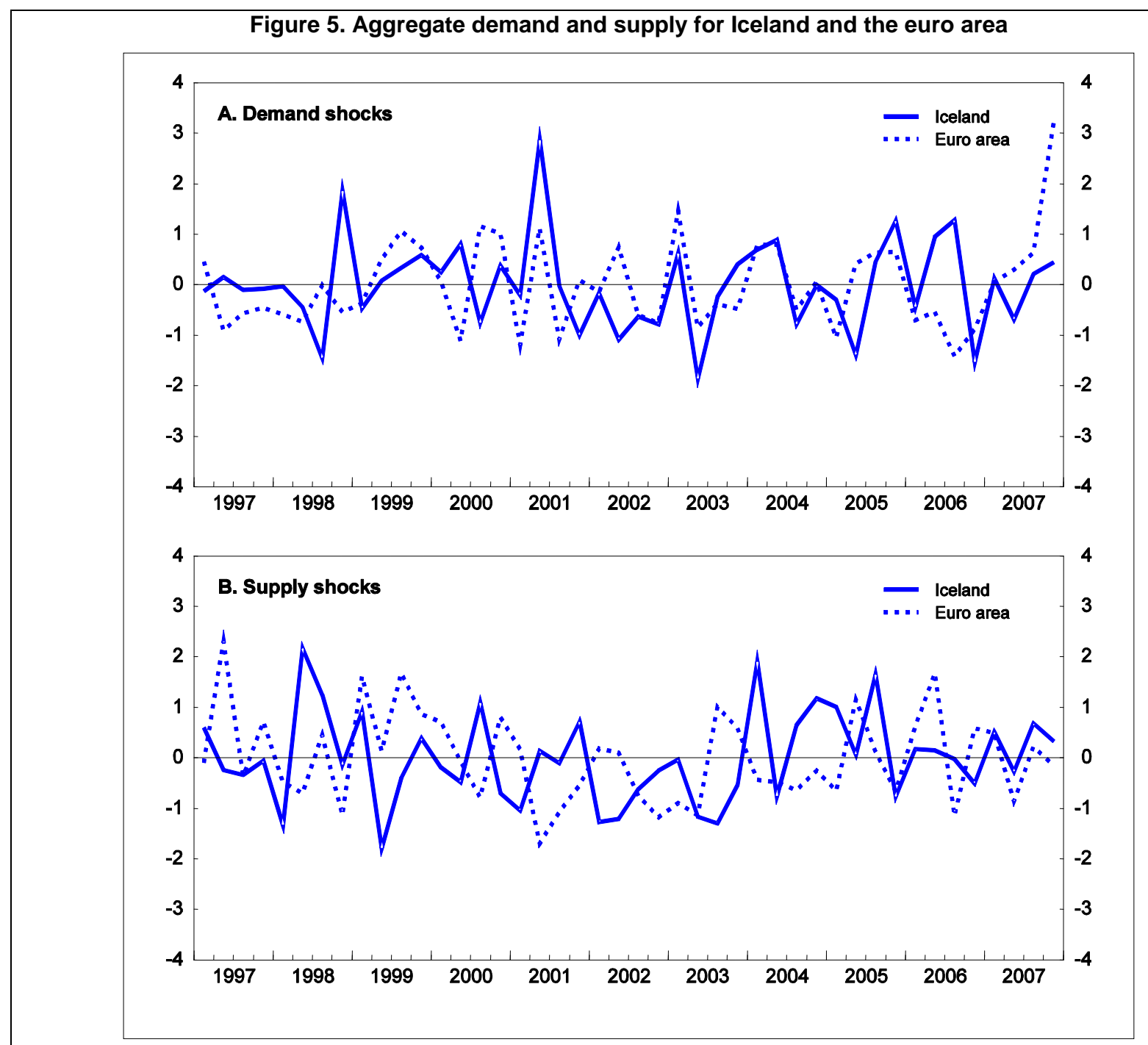

Source: OECD, Main Economics Indicators.

At the same time, comparisons with other countries suggest that the match between Iceland and the euro area may be above a minimum threshold. First, the correlations of the shocks to Iceland with those in other economies also appear to have been relatively low, with the notable exception of Sweden (see Table 2; Figure 6). Second, there are a number of countries inside the euro area which have also been hit by idiosyncratic shocks (see Figure 2.6). In conclusion, this simple analysis finds low synchronisation of cycles between Iceland and the euro area, but this does not appear to be a sufficient condition to discourage Iceland's entry into the euro area.

Table 2 Correlation coefficients of underlying shocks between Iceland and selected countries, 1997-2007 


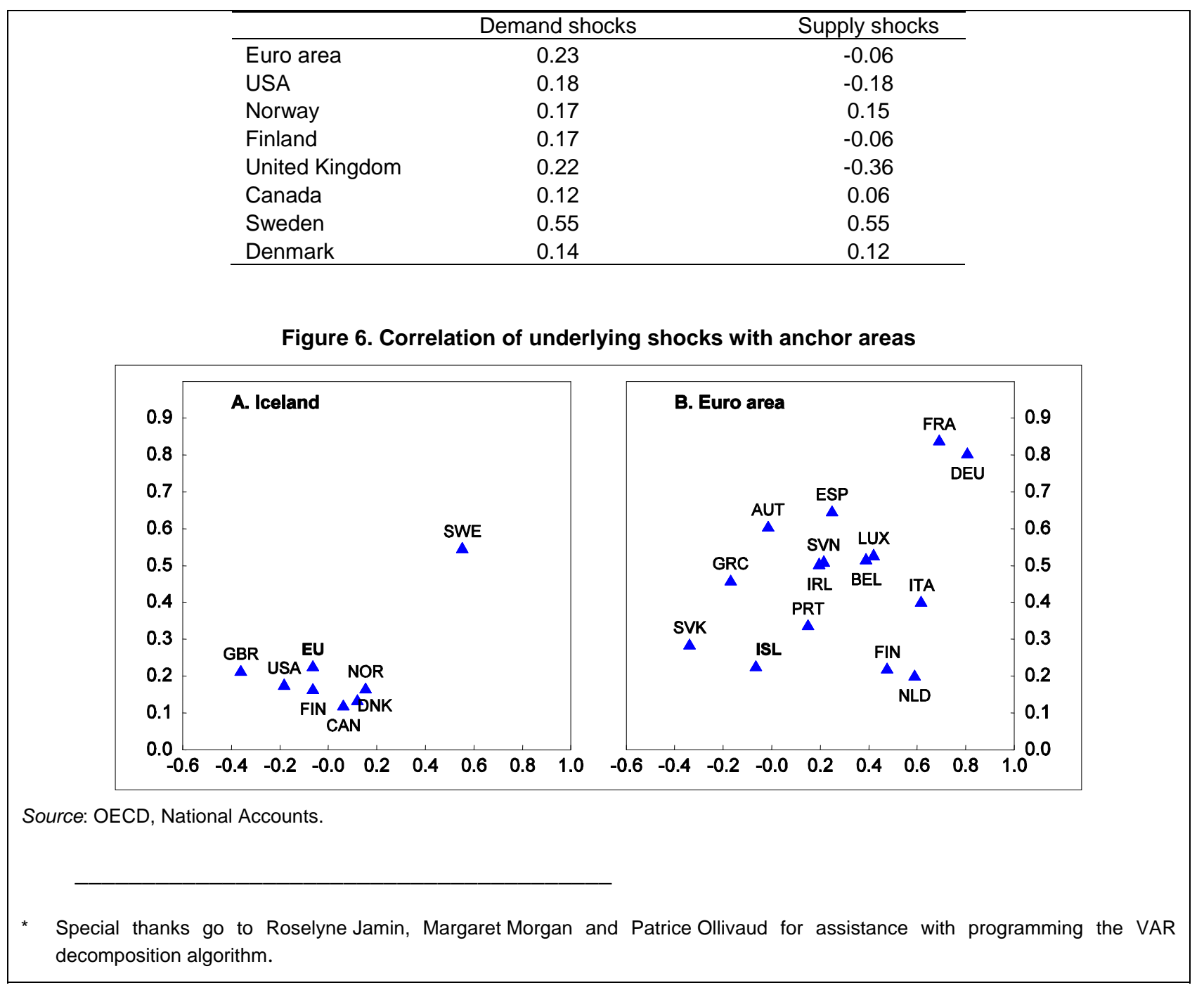

33. The relatively low synchronisation of cycles with the euro area, however, implies that the ECB monetary policy might be suboptimal for Iceland's conditions at times and lead to excessive volatility of prices and output. To avoid excessive volatility, Iceland would need to rely on alternative adjustment mechanisms. Above all, it is important that labour mobility and wage flexibility remain high. While the labour market is flexible overall - even if the OECD Employment Protection Legislation (EPL) index casts some doubts on the actual extent of the flexibility (Box 3) - with high participation rates, easy of entry for migrants, strong work incentives and unemployment benefits of short duration by international standards, Iceland is now facing a massive increase of unemployment for the first time in recent history. Despite the political pressures that the sharp deterioration of labour markets is likely to generate, it is important, especially with the prospect of euro-area entry in a not-so-distant future, to avoid introducing policies that would undermine the good functioning of the labour market. Over time, higher replacement rates and longer duration for unemployment benefits would contribute to a sustained rise in unemployment and hinder macroeconomic adjustment. Other adjustment mechanisms should be improved: capital ought to be able to move freely - in any case the capital restrictions will presumably have to be removed well before euro-area entry - and fiscal policy ought to become more counter-cyclical. Furthermore, given that Iceland's economy is highly specialised in the production of aluminium and fisheries, more unorthodox stabilisation mechanisms, such as hedging against price fluctuations of these commodities, should be considered. 


\section{Box 3. How loose is Employment Protection Legislation (EPL) in Iceland?}

Employment protection legislation refers to all types of employment protection measures concerning hiring (e.g. conditions for using temporary or fixed-term contracts, training requirements) and firing (e.g. redundancy procedures, mandated notice periods and severance payments, special requirements for collective dismissals). While these restrictions are intended to improve job security, they also render the labour market less flexible since they impose additional costs for adjusting the level of employment. The OECD EPL index provides a quantitative assessment of the degree job security by focusing on three main areas: employment protection of permanent workers against individual dismissal; regulation of temporary forms of employment; and specific requirements for collective dismissals. For Iceland, the index was recently computed for the first time using 2008 as a reference for the institutional settings. However, no major legislative change has been introduced in Iceland over the past several years, making the 2008 EPL index also a good approximation for earlier periods.

According to the EPL index, Iceland is characterised by an overall protection for workers which is only slightly below the OECD average and not too far off from Denmark, Sweden and Finland (Figure 7). Distinguishing between the three main employment categories, protection for permanent worker is very close to the OECD average, temporary work arrangements are less tightly regulated than in most OECD economies, and collective dismissals are relatively strict.

The fact that Iceland's EPL index is only slightly below the OECD average was a bit of a surprise since its labour market performance has typically been outstanding by international comparison. There are indeed many elements of Iceland's labour market institutional settings that make it very flexible. Above all, there is no legal right to severance pay and employment relationships can be generally terminated without giving reason. Temporary work arrangements can be made for all types of work and fixed-term contracts can be renewed without restrictions for periods up to 24 months.

At the same type, notification requirements tend to be relatively strict for all employment contracts, and thus restrict employers' flexibility. For example, regular employees with five years of service are entitled to three months' notice. Affiliates of the two largest private sector trade union federations - and $88 \%$ of Icelandic workers belong to a union - are generally entitled to even longer notice periods. In case of collective dismissals, employers also need to consult with the unions and provide them with the opportunity to suggest ways to avoid or limit the layoffs and their impact. Even temporary work agencies have to notify and report regularly to the Directorate of Labour. And workers employed by temporary work agencies enjoy the same rights of regular workers, including the pay and benefits stipulated in collective agreements.

In the typical OECD country, a high EPL score is associated with lower employment rates, especially for individuals at the margin of the labour market (OECD, 2004; Nickell and Layard, 1998). In Iceland, however, the participation rates of all types of workers - including younger, older and female workers - is very high (if not the highest) by international standards. This suggests that the not-so-low EPL score does not seem to have had any noticeable adverse effects in Iceland.

While addressing the shortcomings found by the EPL assessment should not be a top priority for Icelandic policy makers, it is important that they keep a watchful eye to ensure that those features - not captured by the EPL index that have ensured satisfactory labour market outcomes in the past continue to operate in the future. The high degree of real wage flexibility exhibited in the past provides a case in point. Real wage cuts, as in the current downturn, have significantly contributed to macroeconomic adjustments in the face of negative supply shocks. Until now, real wages cuts came about through higher inflation rather lower nominal wages. If Iceland joins the euro area, however, nominal wage flexibility would have to become an important mechanism for adjusting to idiosyncratic shocks. Furthermore, it possible that the not-so-low EPL - in combination with a high degree of unionisation, as is the case in Iceland - may hinder the ability of employers to cut nominal wages when necessary. 


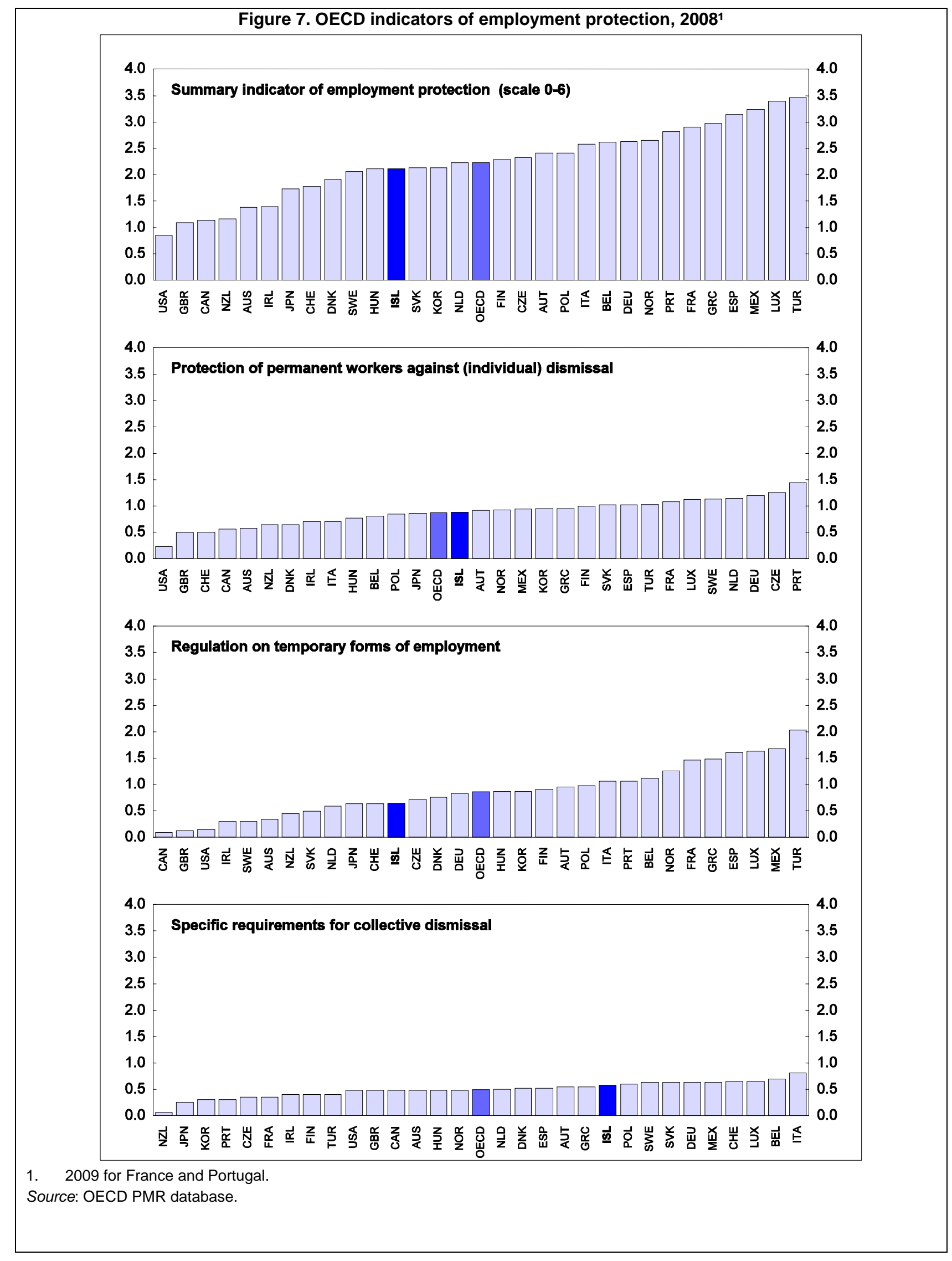


Another reason for Iceland policymakers to be concerned about their country's EPL score is that it may have negative repercussions on product market competition. As for the labour market, the prospect of euro-area entry enhances the case for flexible and well functioning product markets. Research has found that strict EPL causes inefficient firms to stay longer in the market and hoard labour as they face high costs of reducing their workforce. This tends to reduce the entry and exit of firms, thereby lowering product market competition. In addition, if introducing new technologies implies that parts of the labour force have to be shed, strict EPL has the potential to affect a firm's innovation strategy (Bassanini and Ernst, 2002; Gust and Marquez, 2002).

34. While the euro area may not currently fit all the criteria of an optimal currency area (OCA) for Iceland, positive links between income correlation and trade integration may improve business cycle correlation over time (Frankel and Rose, 1997). According to the so-called "endogeneity of OCA hypothesis," a country's suitability for entry into a currency union may have to be reconsidered if satisfaction of OCA properties is endogenous; i.e. if countries satisfy OCA properties ex post even if they do not ex ante. Amongst others, a recent study by Alesina, Barro and Tenreyro (2002) provides some support to this hypothesis, as currency unions are found to increase co-movements of prices and, perhaps, also of output. On the other hand, a competing theory postulates that as countries become more integrated, they will also specialise in those activities for which they have a comparative advantage (Bertola, 1993; Bayoumi and Eichengreen, 1999). According to the so-called "Krugman specialisation hypothesis," members of a currency area are therefore likely to become less diversified and more vulnerable to supply shocks; and consequently their incomes will be less correlated (Krugman, 1993). While there is still no agreement in the literature over which of these two competing theories should prevail (Mongelli, 2002), it nonetheless remains difficult to argue that an economy of roughly 300 thousand individuals constitutes an optimal currency area. In any case, further studies more focussed on Iceland may contribute to the public discussion and reinforce the case for EU and EMU memberships. To this end, the Central Bank's announcement that it intends to update its 1997 report on the establishment and effects of the EMU and prepare a new analytical report comparing alternative models of flexible exchange-rate regimes with various fixed-rate structures is to be welcomed.

\section{The road towards the euro poses challenges}

35. Euro-area entry would not automatically follow membership in the European Union. As all current EMU members, Iceland would also have to satisfy the Maastricht's Treaty convergence criteria. These criteria require that each successful applicant achieves stability and convergence for: inflation; exchange rate; public finances; and interest rates. Most of these requirements could be satisfied without considerable efforts by a developed economy such as Iceland provided that a reasonable degree of macroeconomic stability is achieved (which should be desirable irrespective of the decision of joining the EU and the euro area). At the same time, the road towards the euro will pose some challenges and policy makers ought to be aware of them (Brook, 2005).

36. First of all, the Maastricht Treaty requires achieving price stability before euro-area entry. More specifically, the HICP inflation rate of a successful applicant ought to be no higher than 1.5 percentage point above the average inflation rate of the three "best-performing" EU-member states in terms of price stability. In addition, the achieved degree of inflation convergence should be sustainable. To this end, once the capital account has been liberalised, the authorities should resuscitate and, as recommended above, suitably modify the - temporarily dormant - inflation-targeting framework. Accordingly, the inflation target should be set in conformity with ECB definition of price stability; i.e. of HICP inflation "below, but close to 2\%”. This will not to be easy to attain and may require difficult decisions. At the same, the price stability goal seems within reach, considering that Iceland's HICP inflation averaged only 0.7 percentage point above that in the euro area over the 2001-07 period and that participation in the ERM2 itself should support the CBI’s credibility. 
37. Nevertheless, the definition of "best performing" in the context of price stability creates some uncertainty about the reference value. Initially, the "three best-performers" were simply identified as the three EU countries with the lowest inflation rates. In 2004, however, the Commission decided to exclude Lithuania on the basis that "countries with negative inflation are not considered to be best performers in terms of price stability" (European Commission, 2004). This leaves open the question of whether countries with positive, but very low, inflation rates would be considered best performers; a scenario which might well materialise, if the global recession were to endure longer than currently anticipated. In any case, the definition of price stability provides a moving target for compliance with the criterion, since the composition of countries that meet the "best-performing" criteria will change over time, and their inflation rates cannot be predicted with certainty. In the past, the reference value has ranged between a low of $1.9 \%$ in the second quarter of 1999 and a high of 3.3\% in the second quarter of 2002. For this reason, the Icelandic authorities would have to be prepared to adjust the CBI inflation target as needed. The successful bid of Slovakia to join the EMU indicates that inflation targeting is a reasonable framework to conduct monetary policy towards euro-area entry. At the same time, the domestic authorities ought to stand ready to promptly react to the challenges that they will inevitably have to face (Brook, 2005; Huefner and Koske, 2008).

38. The Maastricht Treaty also requires stabilising the exchange rate before euro-area entry. The criterion for exchange rate convergence entails that the króna participate in the European exchange-rate mechanism (ERM2) for at least two years before euro-area entry. During this period, the króna ought to remain within $15 \%$ bands around a central parity exchange rate which is to be determined. The domestic authorities should therefore pay close attention that the chosen central parity be sustainable. Under the current circumstances, there is much uncertainty about what the equilibrium exchange rate of the króna might be. While the real exchange rate is considerably below its past average, it is not possible to rule out a further drop of the króna when restrictions on foreign exchange transactions are lifted. For this reason, it would be preferable to let the currency float after the capital controls have been removed, and enter ERM2 only once the exchange rate has stabilised.

39. The Icelandic authorities might have to face a tension between the price stability and the exchange rate stability objectives. Balassa-Samuelson considerations should not be as prominent as they have been for EMU applicants from Eastern Europe, since Iceland's GDP per capita is already in line with that of the euro area (Brook, 2005). However, aluminium and fisheries account for most of Iceland's exports; consequently, its exchange rate tends to follow those of other commodity producers, which the euro area is not (Figure 8). It is therefore conceivable that sharp movements in commodity prices might push the value the króna outside the ERM2's bands.

40. The Maastricht Treaty fiscal criterion euro-area entry requires that each successful applicant achieve a budgetary position without an excessive deficit - which is normally defined as a deficit that exceeds 3\% of GDP - and that its gross debt be below, or approaching, 60\% of GDP. Currently, Iceland is far from meeting either. According to the most recent projections, in 2009, Iceland's public deficit will be well above $10 \%$ of GDP and its gross debt will be about 100\% of GDP. As discussed in Carey (2009) and later in this paper, Iceland has entered an SBA with the IMF in November 2008, which requires fiscal consolidation measures of approximately 3\% of GDP per year through 2013. This plan, which the Icelandic government is committed to respect, is expected to yield a primary surplus by 2011 and a surplus by 2013, thus putting public debt on a strong downward path. In sum, the process of fiscal consolidation will surely be difficult but it will be consistent with the EMU application process. Indeed, a policy of euro adoption would facilitate the task of policy makers by making clear the stakes involved in ensuring a sustainable fiscal position. 
Figure 8. Real effective exchange rates in Iceland and other commodity producers ${ }^{1}$

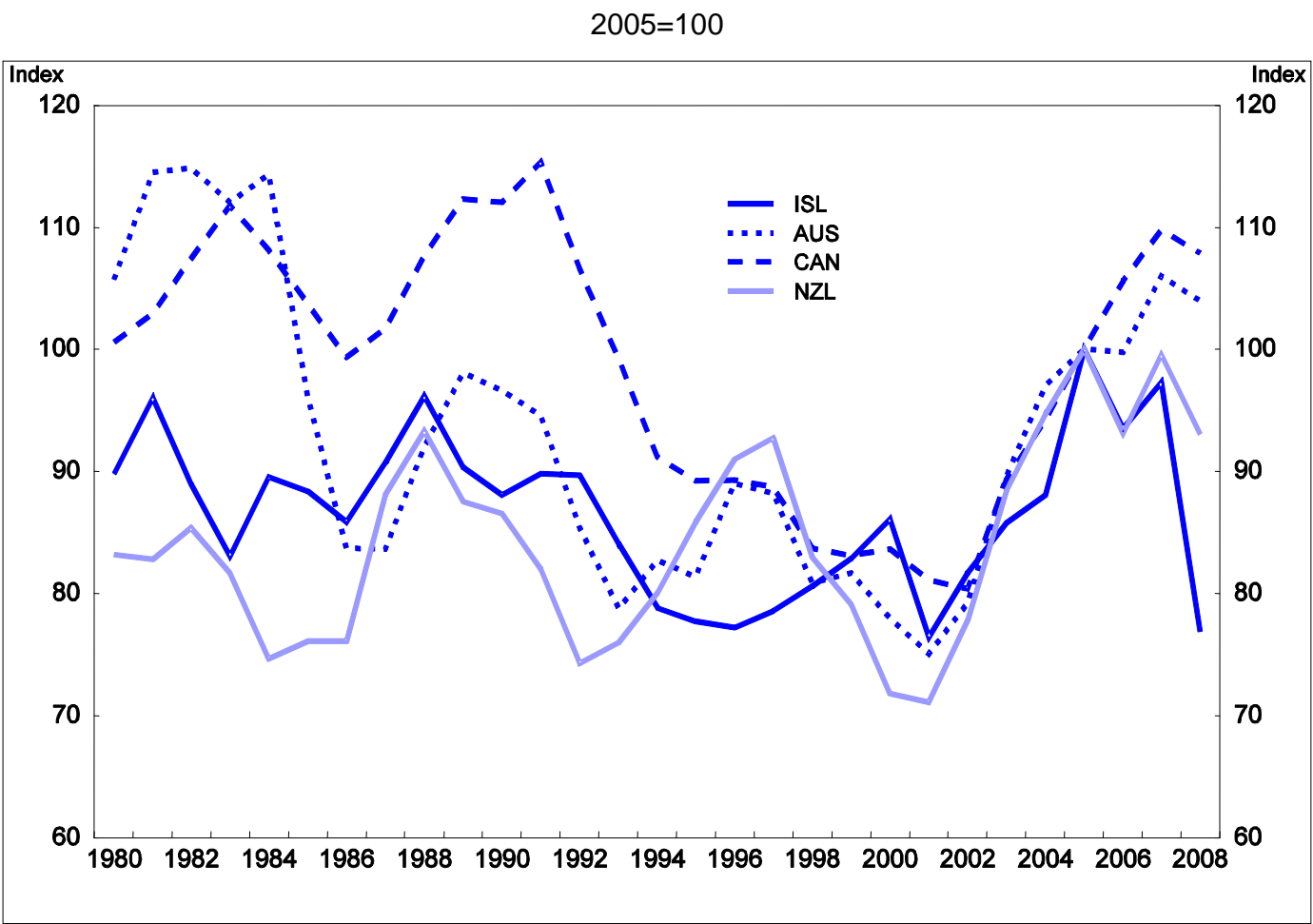

1.

CPI measured.

Source: OECD, Main Economic Indicators.

41. The fourth and final Maastricht criterion of interest rate convergence should not pose additional challenges, as long as monetary and fiscal policies are carried out consistent with euro-area entry. Complications, nevertheless, might arise if the sovereign risk premium were to rise more than currently envisaged, which might occur if the capital controls were to be maintained for several years or no mutually satisfactory agreement could be reached with the creditors of the failed banks.

42. In conclusion, euro-area membership appears to be the best solution for Iceland among its longterm options for monetary policy. The road toward the euro will require difficult decisions, such as the negotiations over Iceland's fisheries. Once inside the euro area, however, the economy should noticeably benefit from the enhanced macroeconomic stability and the reduction in real interest rates. At the same time, some new problems will emerge (starting with the need to keep "changeover inflation" - e.g. from price rounding-up - under control) while some older problems will remain difficult challenges for the domestic authorities (from running a counter-cyclical fiscal policy to managing fluctuations in commodity prices).

\section{Substantial fiscal consolidation measures are urgently needed}

43. Policy makers face an even more difficult challenge with regard to fiscal policy, as the collapse of the banking sector and the sharp recession have put public finances in a dire situation (Table 3). According to the Ministry of Finance's May 2009 outlook, the government debt has already moved up noticeably and is projected to rise further during the course of 2009. While the sharp increase in indebtness is mainly accounted for by the one-time costs resulting from the collapse of the banking sector, as the economy began to sharply contract, public revenues plunged and expenditures, especially on unemployment benefits, increased rapidly. Consequently, government net lending turned negative in 2008 for the first time since 2003, posting an income deficit of 1.2\% of GDP. (And the deficit-to-GDP figure surges to nearly $15 \%$ if the costs of recapitalising the CBI are included.) 
Table 3. General government finances

\begin{tabular}{lcc:cc}
\multicolumn{7}{c}{ Percentage of GDP } \\
\hline \multicolumn{1}{c}{ 1995-02 } & $\mathbf{2 0 0 3 - 0 6}$ & $\mathbf{2 0 0 7}^{\mathbf{1}}$ & $\mathbf{2 0 0 8}^{\mathbf{1}}$ \\
\hline Gross debt & 45.2 & 32.6 & 28.1 & 61.0 \\
Net debt & 27.2 & 15.6 & 7.1 & 26.8 \\
& & & & \\
$\quad$ Revenue & & & \\
$\quad$ of which taxes & 41.4 & 45.4 & 47.9 & 43.4 \\
Expenditure & 35.1 & 39.1 & 40.7 & 36.0 \\
$\quad$ of which public & 42.1 & 43.3 & 42.5 & 44.6 \\
$\quad$ consumption & 22.9 & 25.0 & 24.3 & 24.6 \\
Financial balance & -0.7 & 2.1 & 5.4 & -1.2 \\
Primary balance & 1.4 & 2.3 & 5.8 & -0.9 \\
\hline
\end{tabular}

1. Preliminary figures for 2007 and 2008.

Source: Ministry of Finance, May (2009).

44. The deterioration of public finances requires, as planned, a firm policy response. The present high deficit is cushioning the economy, but cannot be sustained, and adjustment could contribute to a better policy mix. Thus far, the government response has been gradual, as foreseen in the IMF programme. Early in 2009, the government hiked the flat rate on the personal income tax from $22.75 \%$ to $24.1 \%$ and local authorities raised their rates, on average, from $12.97 \%$ to $13.1 \%$. These actions are estimated to yield $1 / 2$ per cent of GDP. At the same time, the government also postponed expenditures - for transfer payments, operational expenditures and investment spending - that had been budgeted before the burst of the crisis. These measures should save $2^{1 / 2}$ per cent of GDP. In May, additional revenue measures - on alcohol, tobacco, gasoline and vehicle licensing - were introduced, narrowing the fiscal gap by a further $1 / 2$ per cent of GDP. The government presented to Parliament in late June a preliminary medium-term fiscal consolidation plan for 2009-13 to achieve balance in public finances, with a final version due to be presented to Parliament in October 2009 along with the 2010 budget proposal. Under the plan, additional taxes were introduced and expenditures trimmed further in 2009, yielding fiscal savings of about $1 \%$ of GDP.

45. The consolidation measures taken thus far represent a welcome step in the right direction, and corrective fiscal measures should continue to be implemented. As described in Carey (2009), the government has repeatedly stated that it is fully committed to respect the Stand-By Arrangement (SBA) which was agreed with the IMF late last year. On the fiscal side, the Arrangement calls for consolidation of approximately 3\% of GDP per year through till 2013 with the aim of attaining a primary surplus by 2011 and a surplus by 2013. In May 2009, the Ministry of Finance's own projections were fully consistent with this plan. The medium-term fiscal plan presented in July entails fiscal savings for 2009 and calls for further radical actions to be taken over the next several years with the aim of restoring fiscal sustainability in line with the economic programme agreed with the IMF. According to the plan, the Icelandic Treasury - the central government - is expected to run a primary surplus of 3.4\% of GDP in 2011 and 8.6\% in 2013.

46. Keeping the public deficit in conformity with the IMF SBA is essential to lay out the foundations for a sustainable recovery. Public finances, which as late as mid-2008 appeared to have been in an enviable state, have quickly turned around after the burst of the crisis at the end of the year. First of all, gross public debt has soared to about $100 \%$ of GDP, in part reflecting the government's assumption of some of the failed banks' debt. While the net costs of honouring the guarantees of the banks' deposits might turn out to be a present value of about $17 \%$ of GDP (see Carey, 2009), the government will have to borrow considerably more to honour these commitments until the banks' assets have been sold. In any case, 
substantial uncertainty remains about the ultimate fiscal costs of the banks' collapse, and thus about the extent of government indebtedness. Another cause of concern comes from the prospect of double-digit public deficits. Some of the increase in the actual deficit is surely due to transitory factors, such as the cyclical increase in unemployment benefits and the cost of recapitalising the CBI; nevertheless, the fiscal gap appears to be structural to a large extent. Simply put, important sources of revenues have vanished and are unlikely to come back. Meanwhile, debt dynamics have worsened. The costs of servicing the larger public debt have risen considerably, and are projected to have risen from $2.4 \%$ in 2003-07 to roughly $10 \%$ of GDP in 2009-10, although, at the time of writing, some uncertainty remains about these estimates. Even so, these projections do not reflect the risk that interest rates on government bonds - which have remained remarkably stable - might increase sharply, once capital controls are lifted. In other words, the authorities should not discount the "funding risk" - that markets might turn drastically against Iceland - when considering the proper stance for fiscal policy. All in all, these considerations indicate that a strong medium-term fiscal consolidation programme, such that envisaged in the IMF SBA, is necessary to restore fiscal sustainability.

47. The fiscal consolidation programme is also an essential step towards euro-area entry. The Maastricht Treaty requires that the public finances of EMU-applicant countries be solid, which, clearly, is not the case in Iceland. As in many other European countries, the goal of euro-area entry could serve to develop a domestic consensus about the adjustment measures called for by the IMF SBA - which are also fully consistent with accession in both the EU and the EMU - and maintain a prudent conduct of fiscal policy after the IMF programme has been completed. After the EU application process has started, the domestic authorities will also benefit from closer collaboration with Eurostat, which will be supervising the collection of statistics, especially regarding public finances. This should improve the quality and comparability of Iceland's statistics, and thus also help restoring the country's international reputation.

48. It will also be important to ensure that the burden of adjustment is distributed fairly. The intention of the government is to reduce the fiscal deficit through both tax increases and expenditure reductions in roughly equal measure, although the weight will have to be towards tax increases in the earlier years owing to the longer lead times for expenditure reductions. With this in mind, the remainder of this paper presents a range of options, focusing first on increasing revenues and then on containing expenditures, the government could consider to restore fiscal sustainability. As the fiscal multipliers associated with public expenditures are generally believed to be larger than those of taxes, at least over the short run (although the issue is far from being settled in the academic literature), it also seems more prudent to put more emphasis initially on the revenue side so as not to unduly restrain the economic recovery.

\section{Measures to increase public revenues}

\section{Immediately reverse the tax cuts implemented over the boom years}

49. The financial crisis and severe economic downturn are having dramatic effects on the revenue sources of Iceland's central government and municipalities. The fall in revenues has been even deeper than that in economic activity as high-income sectors, such as banking and real estate, have been at the epicentre of the crisis and consumer spending, which is highly taxed, has plunged (Figure 9). At the same time, it is likely that the bulk of tax revenues from the financial sector is largely lost permanently - the new banking sector will be much smaller - and that expenditures will have to be cut permanently by a corresponding amount.

50. There were repeated tax cuts over the past several years, which were made possible by the continuous buoyancy of public revenues (Figure 10). The changes made to the structure of personal taxes over the past decade provide a revealing case in point. The personal income tax (PIT), which is the main 
source of revenue for both the central government and municipalities, is levied at flat rate on resident's gross income (excluding income from capital) above a certain threshold (which is typically indexed to inflation). Since 2001, the PIT rate has been reduced from 45.76\% to 35.72\% in 2007 and the tax threshold has tended to rise less than inflation. The valued-added tax (VAT), another important source of income, has also been reduced. While the $24.5 \%$ standard rate applied on most good and services has been kept constant, the reduced rate levied on food and a number of other items was lowered from $14 \%$ to $7 \%$ in March 2007. At the same time, excise duties on several food items were abolished and import duties on meat were reduced. Earlier, in 2005, the wealth tax was abolished; and this list could be longer. Similarly, the corporate income tax rate was reduced from 30\% in 2001 to $18 \%$ in 2007 . The corporate income tax, together with other taxes, was lowered further in 2008 as the authorities, despite warnings that the economic situation was quickly deteriorating, wanted to strengthen Iceland's attractiveness as an international business location. Despite these cuts, government revenues over 2002-07 outpaced GDP (see Figure 9).

Figure 9. Public revenues: recent trends and composition

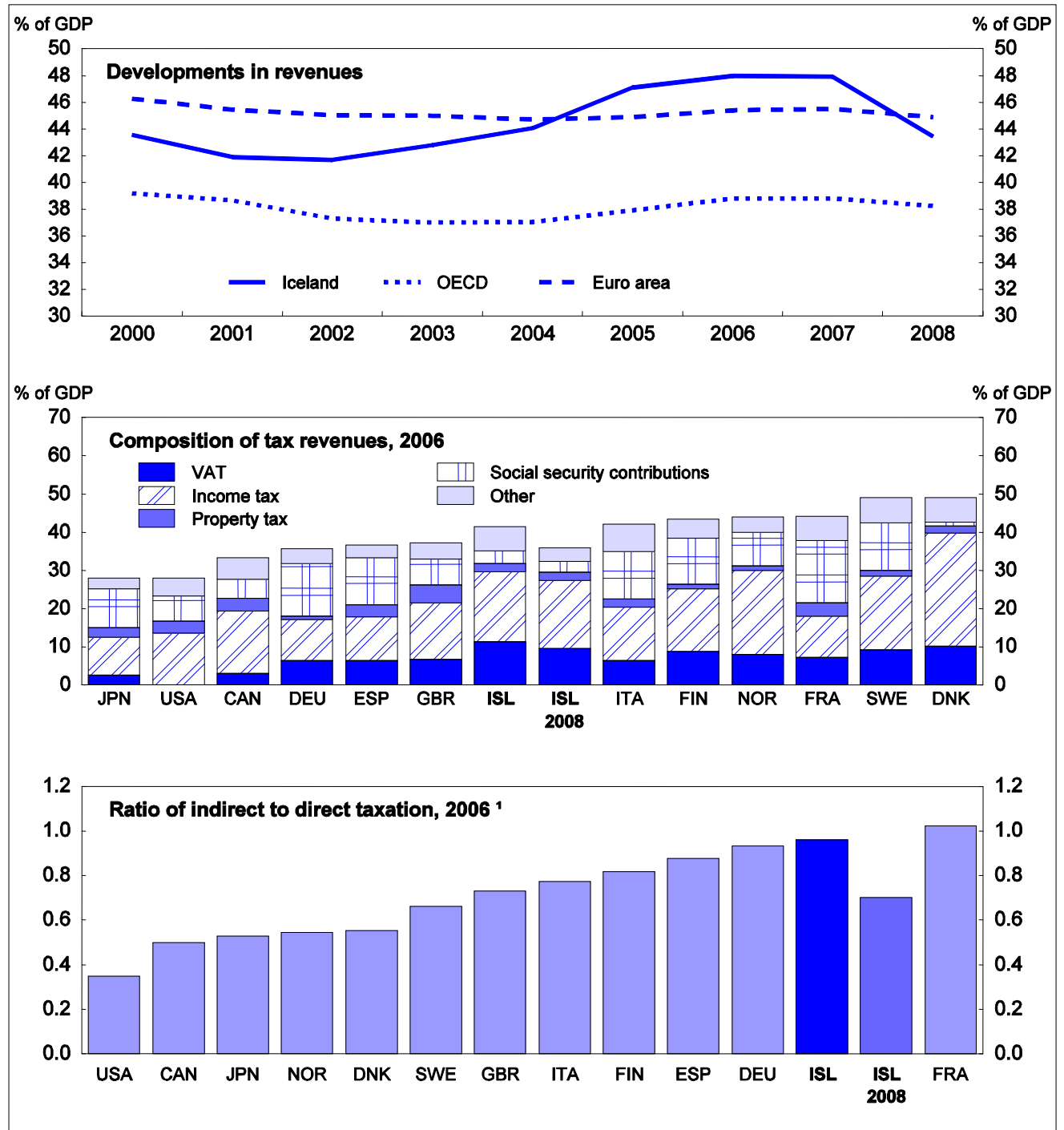

1. Taxes on goods and services divided by taxes on income, profits and capital gains.

Source: OECD, Tax Revenue database and Secretariat's estimates based on preliminary 2008 figures by Statistics Iceland. 
Figure 10. Personal income tax and value-added tax collected by the central government

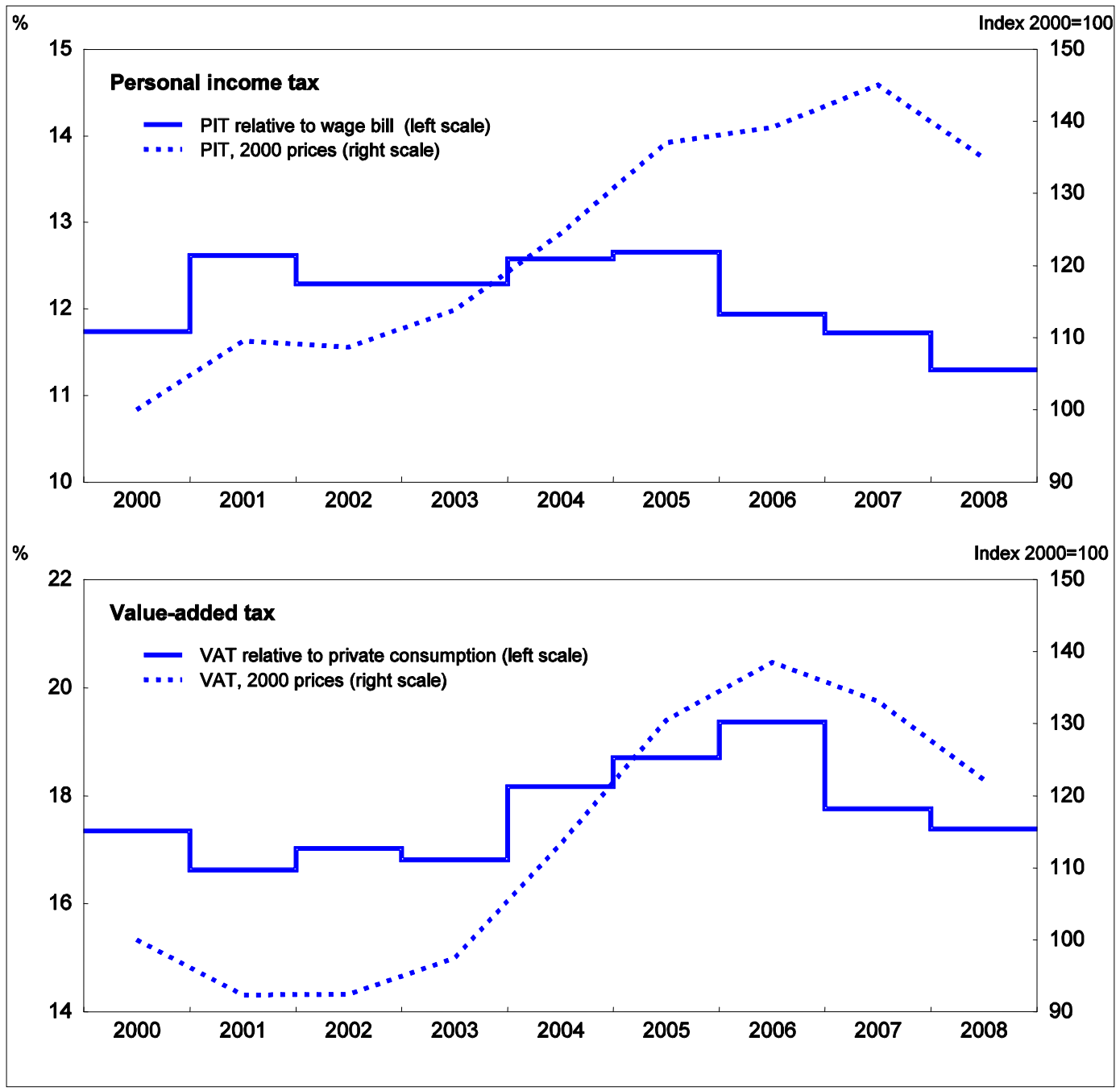

Source: Ministry of Finance.

51. Some of these tax cuts might have seemed justified at the time by the belief that the boom in revenues was permanent. However, as indicated in the 2008 Survey, the 2007 tax cuts occurred at a time just ahead of general elections - when the monetary policy stance had already been tightened as the economy was overheating and other macroeconomic imbalances in the economy were evident. Loosening the fiscal stance at the top of the cycle was wrong; as a result, taxes will have to be raised during the recession. More generally, although fiscal consolidation was considerable during 2002-07, the government, especially with the benefit of hindsight, should have gone further, thereby providing a greater counterweight to the unsustainable boom in private domestic demand.

52. As announced by the government, the starting point for the fiscal consolidation programme should be to reverse the tax cuts implemented over the past decade, which Iceland can no longer afford. Above all, the PIT and the VAT should be raised to the levels that prevailed just a few years ago. There is also room to increase the tax rates levied on corporate income and capital income, and the wealth tax could be re-introduced. As noted above, under the pressure of the deteriorating outlook for public finances, the government has taken actions along these lines. The flat PIT rate was raised by $1.35 \%$ at the beginning of 2009 and excise duties have been raised twice so far during the crisis. In addition, some new measures 
have been introduced in July and additional measures are contemplated in the government fiscal consolidation plan. To boost the PIT, a temporary $8 \%$ surcharge was introduced on high incomes.

\section{Improve the tax system over time}

53. The fiscal authorities will likely have to look for other sources of revenue since, as planned, reversing the past tax cuts will not be enough. In choosing other measures, priority should be given to those that cause the least economic distortions. To this end, following the lead of many of Iceland's Nordic neighbours, a tax could be levied on emissions of carbon dioxide and other greenhouse gases. A carbon tax would produce significant revenues and also discourage the consumption of goods and services that are more harmful to the environment. The case of Sweden provides some insight about the order of magnitude of these effects. In Sweden, the carbon dioxide tax yields slightly more than 3\% of the central government tax revenues (or nearly 1\% of GDP). There is also an annual vehicle tax which depends, amongst other factors, on the amount of carbon dioxide the vehicle emits. As a result of these and other policies, which include generous subsidies for the production of alternative energy, a 2007 government report found that Swedish greenhouse emissions had declined by nearly $10 \%$ since the 1990 s level when the carbon tax was first introduced. For Iceland, where the level of greenhouse gas emission is slightly below that of Sweden even after controlling for the size of the economy, the introduction of a carbon dioxide tax modelled after that one in Sweden could be expected to yield $3 / 4$ per cent of GDP.

54. More generally, there is also scope to reform the tax system. First of all, the relatively simplicity of the Icelandic system is partly offset by the existence of two benefits that are paid through the tax system, the child benefit and the mortgage interest rate rebate. The child benefit could be better targeted to lowerincome households. Currently, the scheme pays about the equivalent of US\$1200-US\$1500 (ISK 15 2000-18 1000) per child to each parent with income up to the equivalent of US\$15000 (ISK 1800 000) and is phased out for higher incomes. As the income threshold for benefit curtailment is about $40 \%$ of 2009 per capita GDP, much of the middle class can take advantage of the scheme. Therefore, there is room to reduce the income threshold without affecting the poor. Similarly, the mortgage interest rate rebate provides a considerable tax relief to the middle class. Early in 2009, as nominal interest payments soared with the rise in inflation and the collapse of the króna, the scheme was expanded to help the increasing share of distressed homeowners. While this might have been justified by reasonable concerns that the number of mortgage defaults could have rapidly escalated, it is also clear that the change provided considerable benefits also to those who did not need them, and it is also making a significant dent in public finances. As the economy recovers and households adjust to the higher interest payments, the tax credit for mortgage interest payment should be quickly reduced. Moreover, as argued in previous Surveys, the authorities ought to consider whether to remove the mortgage rebate. The benefit tilts incentives towards home ownership and high household indebtness, and biases investment decision away from productivity-enhancing business capital spending. An equivalent level of assistance to the lower-income households could be achieved by directly subsidising their home purchases or by expanding the social housing programme. The July consolidation programme, recognising this, calls for stricter means-testing of child- and interest benefits.

55. Over time, more fundamental changes could be undertaken in order to improve the efficiency of the system and allow for higher taxes without harming growth. To this end, the tax base could be widened, further corrective taxes imposed and loopholes closed. For instance, there appears to be scope for reducing the categories of goods and services exempt from the VAT. Under current law, the most common categories of exemption are health services, social services, education, libraries and art, sports, passenger transport, postal services, rental of property and parking spaces, insurance and banking services. While some of the exemptions seem well justified (e.g. health and social services), Iceland policymakers should re-examine whether the preferable tax treatment is warranted for all. 


\section{Make sure the unemployment benefit system is properly funded}

56. The sharp increase in the unemployment rate has put the unemployment benefit scheme under considerable pressure, which is likely to intensify if the recession deepens, as projected. The authorities anticipate that the fund from which the benefits are paid out will be extinguished before the end of the 2009. According to the Directorate of Labour, ISK 21.5 billion (about 1.5\% of 2009 GDP) are required to continue operating the scheme over this year and next. For this reason, taxation for the full funding of the unemployment insurance scheme was provided in new legislation in June.

57. The fast depletion of the unemployment insurance fund has been the result of rapidly deteriorating labour market conditions. Previously, for over thirty years, Iceland's labour market outcomes had been remarkably positive - on average, nearly $80 \%$ of the adult population has been employed since 1991 - in part reflecting a low EPL index (box 3). The registered unemployment rate, which had averaged only $2 \%$ over $1980-2008$ and was running below $1 \%$ as recently as 2007 , soared quickly after the burst of the crisis and, by June, had risen to $8.1 \%$. The unemployment insurance fund, which, until July 2009 was financed by a relatively low (0.65\%) payroll tax, was not set up to cope with such a large number of claimants.

58. The Icelandic authorities are taking proper action to ensure that unemployment benefits will continue to be paid. First of all, the scheme does not appear to be overly generous, especially considering that the unemployment rate is projected to remain elevated for quite some time. The scheme pays a benefit up to $70 \%$ of the last salary for the first three months and a reduced fixed amount for three more years. After that, those who remain unemployed, if they qualify, fall into the general welfare schemes. In addition, the individuals receiving unemployment benefits are required to participate in active labourmarket programmes and are strongly discouraged from rejecting jobs offered by the government's employment agency - each job refusal entails the loss of benefits for forty days. Moreover, the Directorate of Labour, in agreement with the social partners, has utilised the resources in the fund to discourage lay-offs. In May, 20\% of those collecting (reduced) unemployment benefits were working part-time. Last but not least, minimising the social costs of the crisis will also help to create the political consensus for the necessary fiscal consolidation measures.

59. The resources to cover the gap in the unemployment insurance fund will also have to come from higher future contributions. The payroll tax was increased to a level that is expected to balance the fund's accounts over the economic cycle. Alternatively, the authorities could have considered financing the unemployment benefits scheme by introducing a layoff tax, which firms would have to pay when they dismiss workers. As argued by Blanchard and Tirole (2003, 2008), payroll taxation goes the wrong way for two reasons: the absence of layoff taxes leads firms not to internalize the costs of insurance and, by increasing labour costs, the presence of payroll taxes gives incentives to firms to lay workers off. In addition, to keep the fund solvent, the authorities should also consider whether to means test the benefits.

\section{Measures to contain public spending}

\section{Hold back public-sector wages and public investment}

60. The planned fiscal consolidation will necessarily also entail substantial measures to reduce public spending. In recent years, public expenditures increased at a pace similar to that of GDP (Figure 11). Now that the economy has contracted sharply, which to a large extent appears to be a permanent change, public spending will also have to be scaled back significantly. While it may be difficult to reduce expenditures rapidly, the government should continue developing its plan for how it intends to contain public spending over the next few years. 
Figure 11. Public expenditures: recent trends and composition

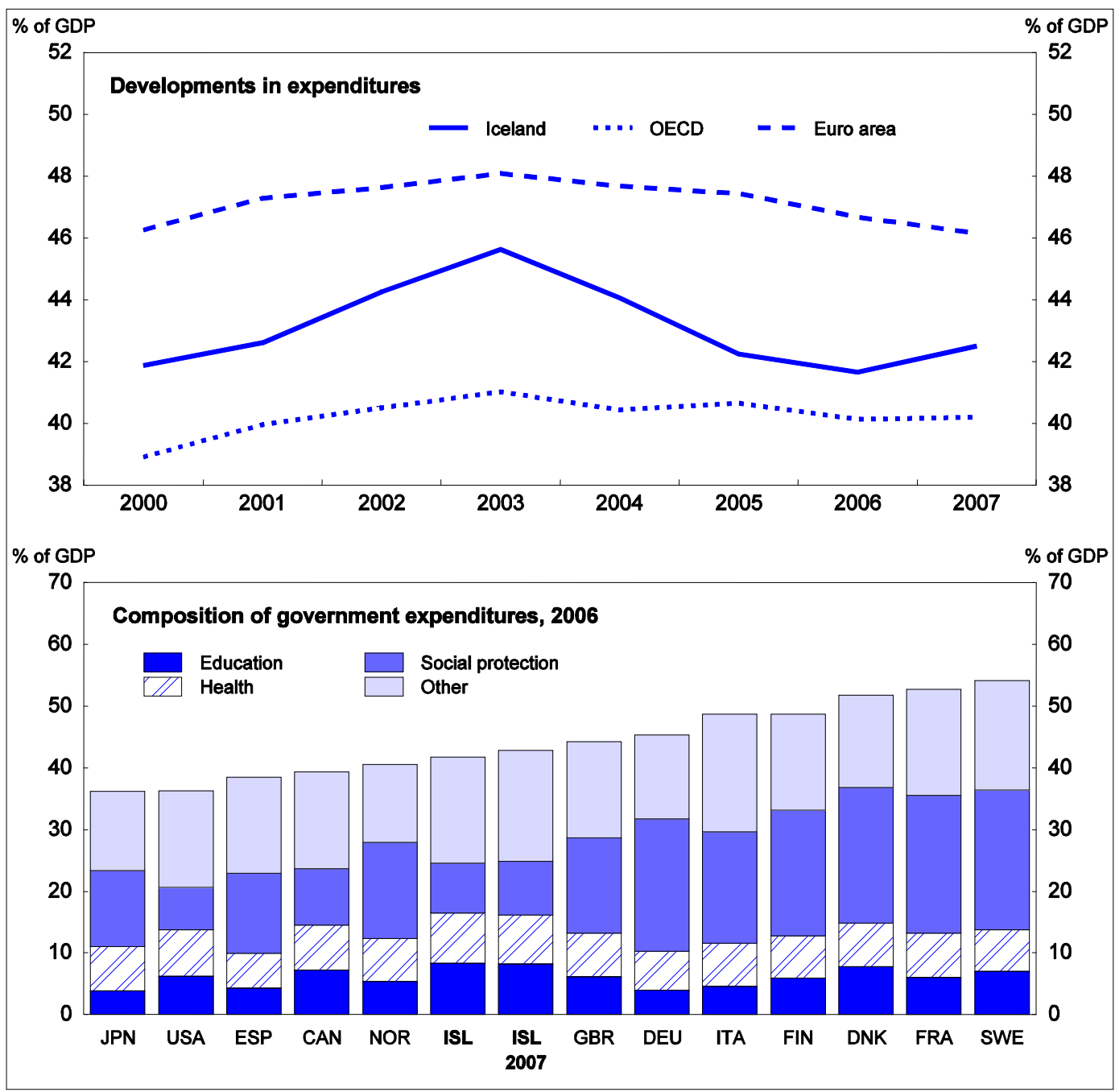

Source: OECD, National Accounts and Secretariat's estimates based on preliminary 2008 figures by Statistics Iceland.

61. Just like for taxes, expenditure areas that expanded rapidly during the boom years are good areas to look at for savings as they were not considered to be a priority when Iceland was less prosperous, a situation that it now finds itself in again. Both public-sector wages and public investment increased rapidly in recent years and, consequently, should be now scaled back, as planned. Such measures would also yield considerable savings in the near term, whereas other plans - discussed later in this paper - might restrain public spending only over a longer time horizon. Government real wage rates received a significant boost in recent years, as the then booming financial sector raised the demand for more skilled workers. On average, public-sector real wage rates increased by $2.7 \%$ per year over 2003-07 (see Figure 16). With retention no longer a problem and wages counting for a large share of public spending, a freeze, or perhaps even a cut, of nominal wage salaries in the public sector would result in a significant decline in real government expenditures, at least in 2009. In any case, considering that most public-sector workers are not at risk of losing their job, their wages should grow well below those in the private sector at least until the fiscal consolidation goals have been met. Similarly, public investment, which rose at an annual average rate close to $12 \%$ over the 2003-07 period (see Figure 12), should also be scaled back as much as possible. To this end, the government, as planned, should consider imposing a moratorium on all non-essential public infrastructure projects. 


\section{Improve the fiscal policy framework}

62. Substantial savings could also be achieved over time by improving the framework for conducting fiscal policy. As discussed in the 2008 OECD Survey, in the past, public expenditures have frequently grown faster than planned by the authorities. In 1992, a top down "frame budgeting" approach was introduced to set spending limits for each of the ministries and their agencies. In 2003, the approach was supplemented by the adoption of spending rules, setting growth ceilings for real public consumption and real transfers. However, fiscal discipline continued to be less than satisfactory. The National Audit Office repeatedly observed that a significant number of ministries and public agencies significantly overspent their budget year after year. In 2006, it found that two-thirds out of around 300 budgetary items were outside the $4 \%$ deviation allowed for in the regulations concerning budget implementation, a practice that clearly undermined stated government objectives. In practice, these rules seem to have been more a forecasting exercise than a means of budgetary restraint. With no mechanism in place to ensure that targets were met, each annual budget typically presented an update of the previous medium-term plan starting from a higher expenditure level. While the lack of fiscal discipline might have not been perceived as an urgent problem when the economy was booming and public revenues were rising rapidly, this is no longer the case.

63. The challenge of improving the budgeting framework should not be delayed any further. Achieving the fiscal consolidation agreed under the IMF SBA will be much less difficult if budget expenditures growth ceilings are met. To this end, ministries and public agencies should have to make up for any expenditure in excess of their authorised budget ceilings in the following years; equally, they should be able to carryover credits for under-spending, thereby avoiding a rush of wasteful spending at the end of the year. In addition, the National Audit Office should be given more authority to monitor the implementation of the budget. Looking further ahead, managers need to be given greater autonomy and held accountable for meeting objectives.

64. The government should announce spending targets and overall fiscal objectives over a multi-year horizon. Compliance with these targets and objectives should be verified regularly, and results should be made available to the public. There should be political costs for failing these objectives, and rewards for achieving them. Transparency would be enhanced if the spending limits were set in nominal rather than in real terms as in the past, which would also increase the government's ownership of the goal of controlling inflation. If the government is determined to lead Iceland into the euro area, public spending, and especially public-sector wages, should increase at a pace consistent with the Central Bank inflation target, which often was not the case in the past. Switching to a nominal multi-year budgeting plan would not only strengthen the medium-term orientation of expenditure policy and budget discipline but would also enhance the contribution of fiscal policy to macroeconomic stabilisation.

\section{Implement cost-cutting structural reforms}

65. Aggressive fiscal consolidation efforts will also have to be directed to cut spending in the large public spending programmes. International comparison indicates that Iceland's public spending in health care and education is high in relation to GDP (see Figure 11). Furthermore, Iceland's relative performance - measured by outcome versus GDP per capita - in health and, especially, education indicates that there might be scope for structural reforms in these areas (Figure 12). Admittedly, this constitutes a difficult challenge for Icelandic policy makers since spending cuts in health care and education spending are never politically popular. With this in mind, reforms should be designed to achieve the same outcomes at lower costs. 
Figure 12. Performance in health and education

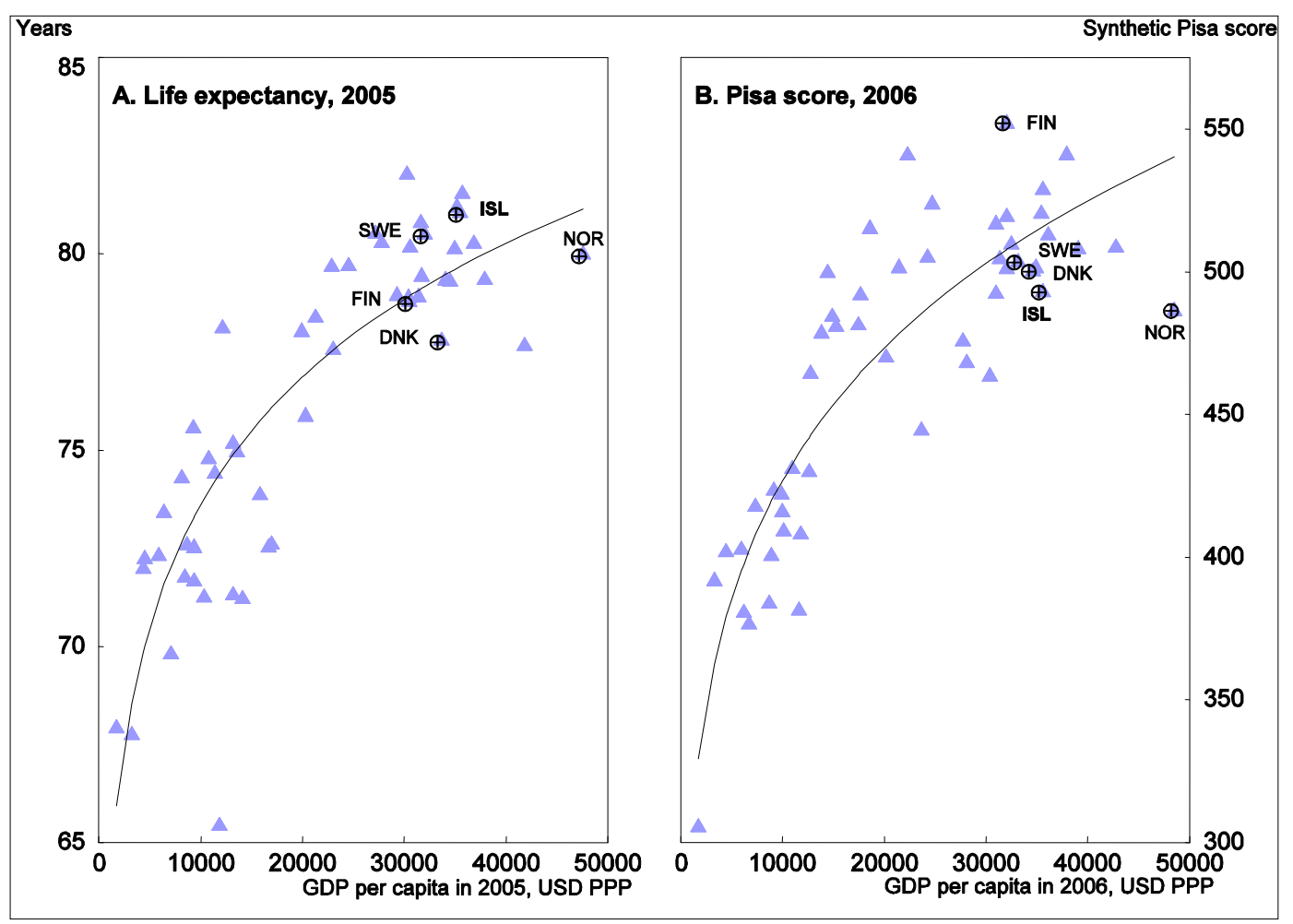

Source: World Bank WDI database; OECD PISA Results.

66. To be sure, health outcomes and the quality of health services are very good by international standards. Life expectancy is among the highest in the world. Perinatal and infant mortality are the lowest, and maternal mortality virtually non-existent. Icelanders can expect to be healthy for about $90 \%$ of their long lives. Recent indicators of the quality of care (for instance, survival rates for certain illnesses and inhospital case-fatality rates) also show Iceland in a very favourable light. It is important that proper care is taken to maintain the high-quality health services, which contribute to the enviable health status of the Icelandic population. However, empirical estimates, which take into account a wide range of health determinants, suggest that, reflecting declining returns to scale, every further health gain may come at a very high price, while maintaining the present excellent health status should be possible at lower levels of resource use and expenditure (Alfonso et al., 2005). For example, although the geography and population distribution of the country probably justify an above-average share of health-care workers, staffing ratios seem excessive by international comparison.

67. The 2008 OECD Economic Survey of Iceland recommended several options for enhancing spending efficiency in the health care sector (OECD, 2008; Suppanz, 2008). To begin with, impediments to private provision, which accounts for only one quarter of publicly financed health-services, should be removed and the sector opened up to competition. But when services are outsourced to the private sector, the authorities need to have the necessary expertise and resources to design appropriate service contracts and monitor the outcomes. To avoid that increased patient choice overly stimulates demand for services, cost-sharing should be introduced where it does not exist (hospitals) and reformed where it does not provide sufficient incentives for cost-savings (for instance, pharmaceuticals). In addition, or alternatively, the authorities could consider introducing a form of gate-keeping system in which patients are directed to the most appropriate level of care. Another policy priority should be to accelerate the implementation of activity-based funding in hospitals, which account for a high share of health care spending in Iceland. Within a robust regulatory framework, output-related prospective payment systems can encourage 
providers to minimise costs without hurting patient care if associated prices are set correctly and there is appropriate control of quality. The authorities should also make use of the scope provided by a high degree of centralisation to increase efficiency. What is clearly needed is a prioritisation of public health care spending based on cost-benefit analysis of different kinds of services. Also, the government should make more use of its power as the main buyer of health services to reduce costs, by putting downward pressure on prices or shifting care to less expensive services.

68. Admittedly, it is very difficult to gauge the extent of the savings that could result from implementing reforms along these lines. One methodology often used to assess the efficiency of social spending is Data Envelopment Analysis (DEA), a technique that allows an efficiency frontier to be estimated through a cross-section comparison of the social outcomes in question to various monetary and non-monetary inputs (Box 4). For health spending, outcomes are typically proxied by life expectancy at birth, while total health spending per capita, GDP per capita, and fruit and vegetable consumption per capita are used as input variables (Joumard et al., 2008). Deviations from the estimated efficiency frontier indicate inefficiencies. In particular, it is "input efficiency" - that is the minimum bundle of inputs to produce a given output - which provides the relevant measure for the potential cost savings.

\section{Box 4. Measuring the efficiency of social spending}

The analysis conducted for this paper estimates an efficiency frontier that relates outcomes of the health and education system to monetary and non-monetary inputs through Data Envelopment Analysis (DEA) based on the work conducted by the Secretariat in Sutherland et al. (2007), Joumard et al. (2008) and most recently in the context of the 2009 Survey of Mexico (OECD, 2009b; for a more complete account, see Schwellnus, 2009). The method uses linear programming techniques to construct a frontier from the most efficient observations, which "envelop" the less efficient ones (Figure 13).

\section{Figure 13.Efficiency frontiers}

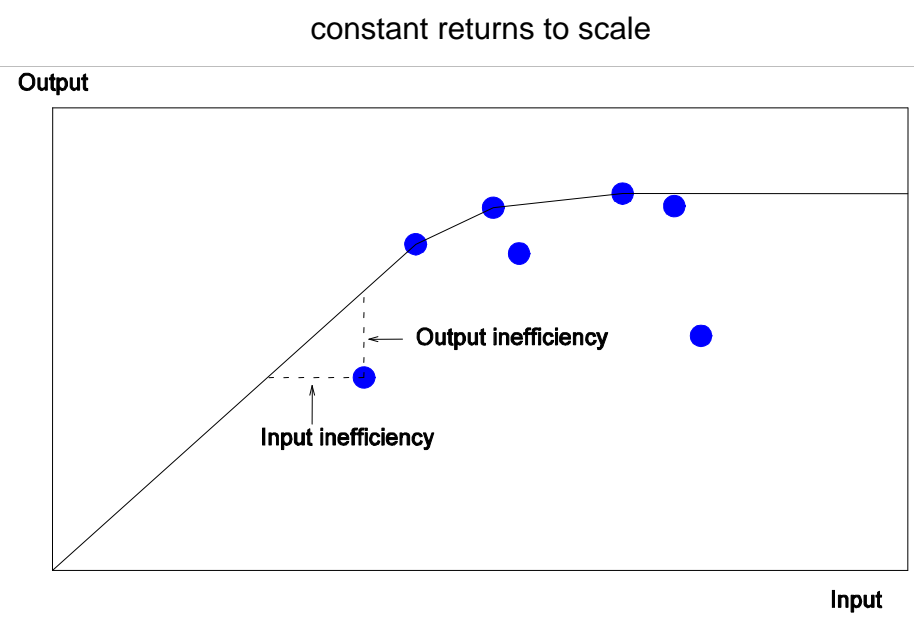

Source: Sutherland et al. (2007).

The method distinguishes between input and output efficiency, and technical and allocative efficiency. Input efficiency requires the use of a minimum bundle of inputs to produce a given output, while output efficiency requires the maximum amount of output from a given bundle of inputs. Allocative efficiency is more relevant than technical efficiency as it requires cost minimisation or benefit maximisation. This paper uses input efficiency in the allocative sense to measure efficiency of social spending in Iceland. This is the appropriate concept for the Icelandic case in that, rather than minimising the gaps in health and education outcomes, the main objective of the Icelandic authorities is to reduce costs while maintaining the current outcomes. Technical efficiency allows conclusions on the efficient use of physical health inputs to be drawn but not on the efficiency of spending.

While the DEA analysis provides an attractive summary measure of efficiency of spending, it has a number of drawbacks that have to be addressed in its practical implementation. 
- Sensitivity to small samples. If the sample is small, the efficiency level is likely to be overestimated because the most efficient country is likely to be excluded from the sample. The efficiency scores reported in this paper are therefore corrected for small sample bias through the bootstrapping procedure proposed by Simar and Wilson $(1998,2000)$. Note that due to the small sample correction procedure, no country is found to be on the efficiency frontier.

- Sensitivity to the number of included inputs and the form of the efficiency frontier. Only a limited number of inputs can be included in the estimation and an assumption on economies of scale in production has to be made. The efficiency scores reported in this paper are robust to various sensitivity checks on included inputs and economies of scale. On grounds of economic plausibility, only efficiency scores using the assumption of constant returns to scale are reported.

- Sensitivity to outliers. A country that has an atypical combination of inputs and outputs is likely to be classified as efficient because there are no appropriate comparator countries in the sample. For this reason, developing countries - included in Schwellnus (2009) - are excluded from the sample for the results reported in this paper.

69. DEA-based estimates indicate that Iceland could reduce spending by one-half without compromising health outcomes if it were able to reach the efficiency frontier (Figure 14). Reaching the goal of being on the efficiency frontier is, however, beyond the scope of Iceland, at least in the foreseable future. No country is found to be on the efficiency frontier since the efficiency estimates are computed using a small sample correction procedure. For this reason, a comparison with the level of efficiency attained in other OECD countries, rather than with the estimated frontier, might yield a more reasonable gauge of the potential savings resulting from implementing the cost-cutting reforms discussed above. If one assumes that these reforms could boost the input efficiency of the Icelandic health system from the current level - which is about the OECD average - to that of Spain (Finland is not far off), which is the first quartile in the distribution, then it would be possible to save $17.5 \%$ of spending while maintaining the same health status. As public health spending has averaged about 8\% of GDP in recent years, this means that yearly savings of $1 \frac{1}{2}$ per cent of GDP could be achieved over time without compromising health outcomes.

Figure 14. Input efficiency of the health system

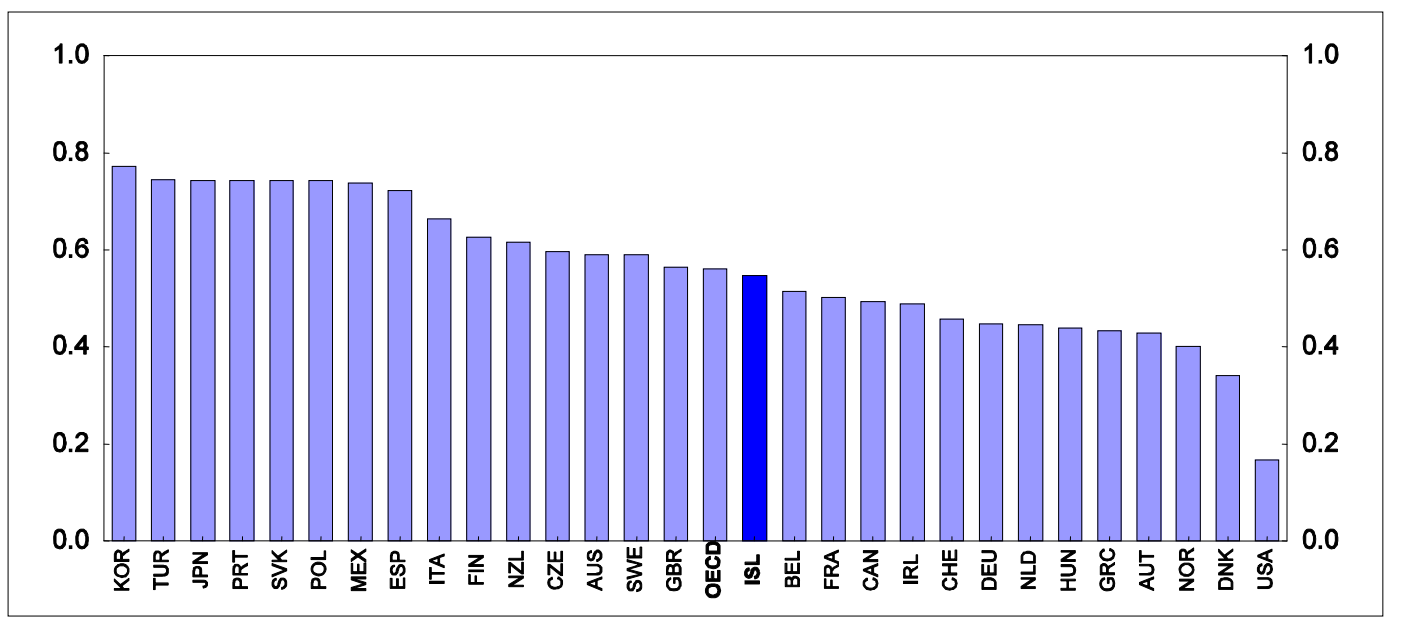

Source: Schwellnus (2009), using OECD, World Bank, World Development Indicators database; FAO, Faostat database.

70. The scope for enhancing spending efficiency in the education sector appears to be even greater than for health care (see Figure 12). For a long time, Iceland's educational achievements, as measured by PISA test scores, have been disappointing compared to those of other countries despite the substantial resources invested. Reflecting a general trend towards decentralisation in Iceland as well as the belief that the educational system should be more responsive to local needs, the responsibility for compulsory 
schooling (up to the age of sixteen) was transferred to municipalities in the mid-1990s. The reform, however, has not produced satisfactory outcomes: spending per student has increased, as additional resources have been devoted to reduce the (already low by international comparison) teacher-to-student ratio, but educational achievements, especially in rural areas, have remained low (Figure 15). Icelanders also spend an unusually long time to complete upper-secondary education, with most students taking the university entrance examination only at the age of 20. Consequently, relatively few students complete their studies, contributing to maintaining a persistent gap between the low skilled and high skilled in the labour force, despite high public spending by international comparison. Resources invested in higher education have also increased rapidly in recent years as the authorities tried to offer a more comprehensive system, rather than encouraging studies abroad, in the face of an explosion in enrolment.

\section{Figure 15. Pisa score and education spending per student}

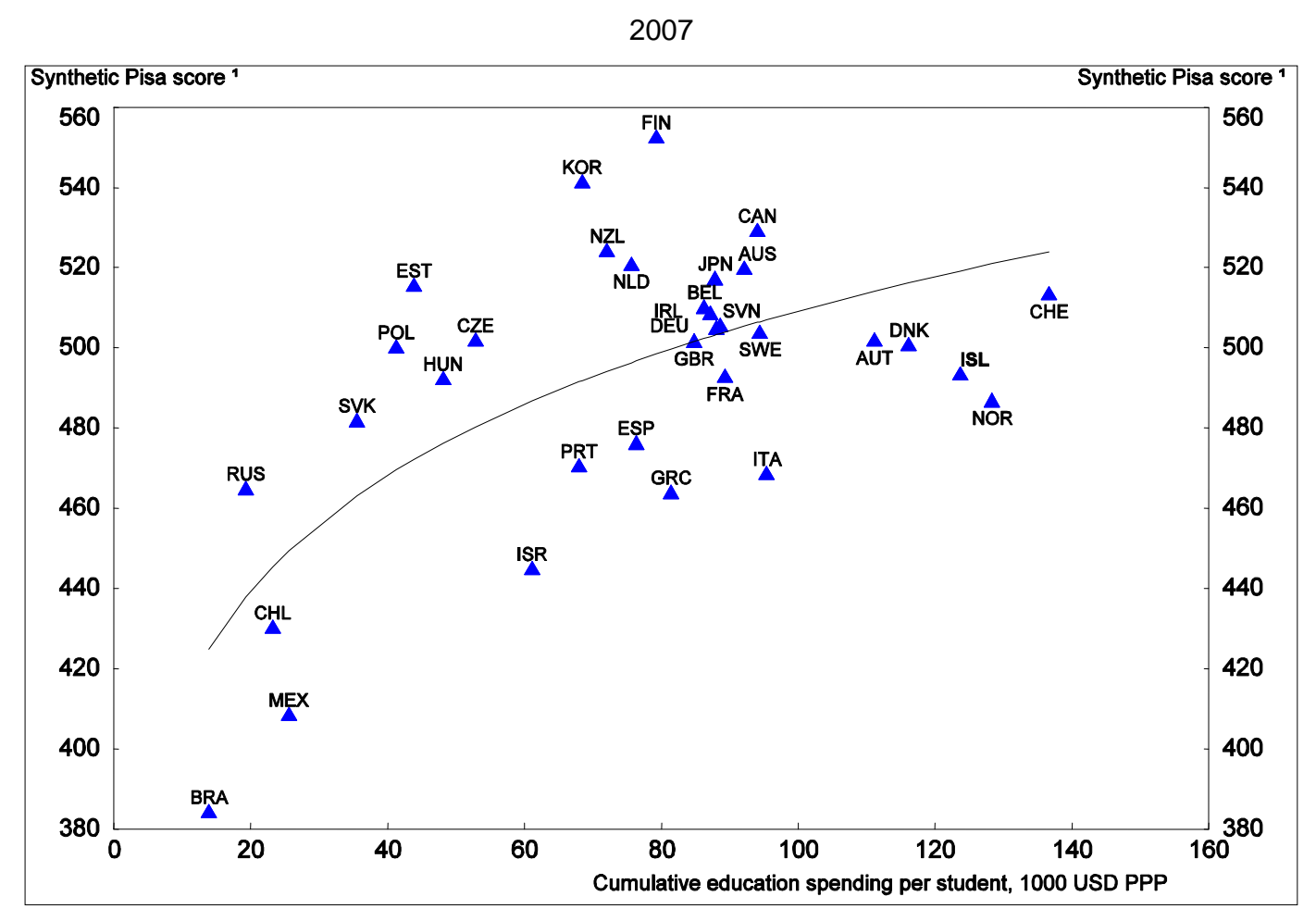

1. The synthetic PISA score combines the scores on the reading, mathematics and science scale through factor analysis.

Source: OECD, PISA Results 2006.

71. The 2006 OECD Economic Survey of Iceland pointed out these deficiencies and recommended that the authorities undertake a series of measures which promised not only better outcomes but also lower costs (OECD, 2006; Suppanz, 2006). Such reforms should not be delayed any further. Municipalities, which are responsible for pre-school and primary education, will be obliged to cut spending in these areas as their revenues have fallen and their access to external financing sources is limited. To this end, they should require teachers to work longer hours - net teaching time at the compulsory level in Iceland is among the lowest in the OECD - and increase pupil-teacher ratios and class sizes. Such a reorganisation would entail cost savings and might also have a positive effect on educational achievements by improving the average quality of teachers. Reorganisation to close very small schools in rural areas would also be beneficial. For upper-secondary education, the government should step up its efforts reduce the length of studies. As planned, shortening the duration of upper secondary education from four to three years, as in the other EEA countries and in accordance with the Bologna Agreement, would entail significant savings while allowing young people to commence their university studies one year earlier and extending their 
working career and lifetime income. There is also scope for consolidation in the higher education sector. Instead of trying to offer a full range of tertiary programmes, studies abroad should be encouraged, in particular at the graduate and doctoral stages of higher education. Public universities, which will likely face severe budget constraints, should be given the possibility of charging fees rather than cutting their programmes. The experience of countries that have combined an increase in education fees with an improvement in student loan facilities suggests that there are no significant adverse effects on participation (Blondal et al., 2002).

72. As for health care, efficiency frontier analysis can help gauge the extent of the cost savings that structural reforms, as those highlighted above, could entail for the education sector. In this case, the outcome variable used in the analysis is a synthetic PISA score that combines the reading, mathematics and science scores through factor analysis. The input variables are education spending per student and the PISA ESCS index, a proxy for contextual factors. As Iceland's PISA score is slightly below the OECD average while its spending per student is $40 \%$ above average, it should not be surprising that Iceland turns out to be far from the frontier. In other words, a number of OECD-member countries, including Finland and Sweden, are able to achieve higher educational outcomes at lower costs.

73. The results from the efficiency frontier analysis confirm that Iceland is one of the least efficient among OECD countries in education spending (Figure 16). More specifically, the DEA-based estimates indicate that Iceland could reduce education spending by $21 \%$ without sacrificing outcomes by adopting reforms to raise the input efficiency to the OECD average. Lifting input efficiency to the frontier or even to Finland's level would entail much greater savings. In any case, given the dire state of Iceland's public finances, domestic authorities should be setting the reasonable goal of raising the input efficiency of the education spending at least to the OECD average. This would entail fiscal savings of $1 \frac{1}{2}$ per cent of GDP per annum. A good starting point to this end would be to accelerate the implementation of the reform to upper-secondary education curricula. The Ministry of Education estimates that this should shorten the duration of studies by one year for $40 \%$ of the students, reducing education spending by 1 million króna per student who finishes earlier. Accordingly, the reform, when fully implemented, should yield savings of about $0.2 \%$ of GDP. In other words, this is a welcome first step but falls short of what the government's objectives should be.

\section{Increase the efficiency of spending by municipalities}

74. National spending objectives cannot be achieved without effective co-operation between the central government and the municipalities. First of all, expenditures by local governments account for about one-third of the overall level and the municipalities are responsible for the provision of politicallysensitive services, such as compulsory education, assistance for the elderly and housing for low-income families. In addition, municipalities have some limited taxation powers on income and real estate property, which provide approximately $70 \%$ of their income. During the boom years, local revenues increased rapidly, and, municipalities exhibited even less restraint than the central government in spending these windfall resources (Table 4). Accordingly, they expanded public services and increased pay for their employees. Now, however, with only limited access to capital markets, they have little choice but to adjust spending to the considerably lower revenues. 
Figure 16. Input efficiency of the education system

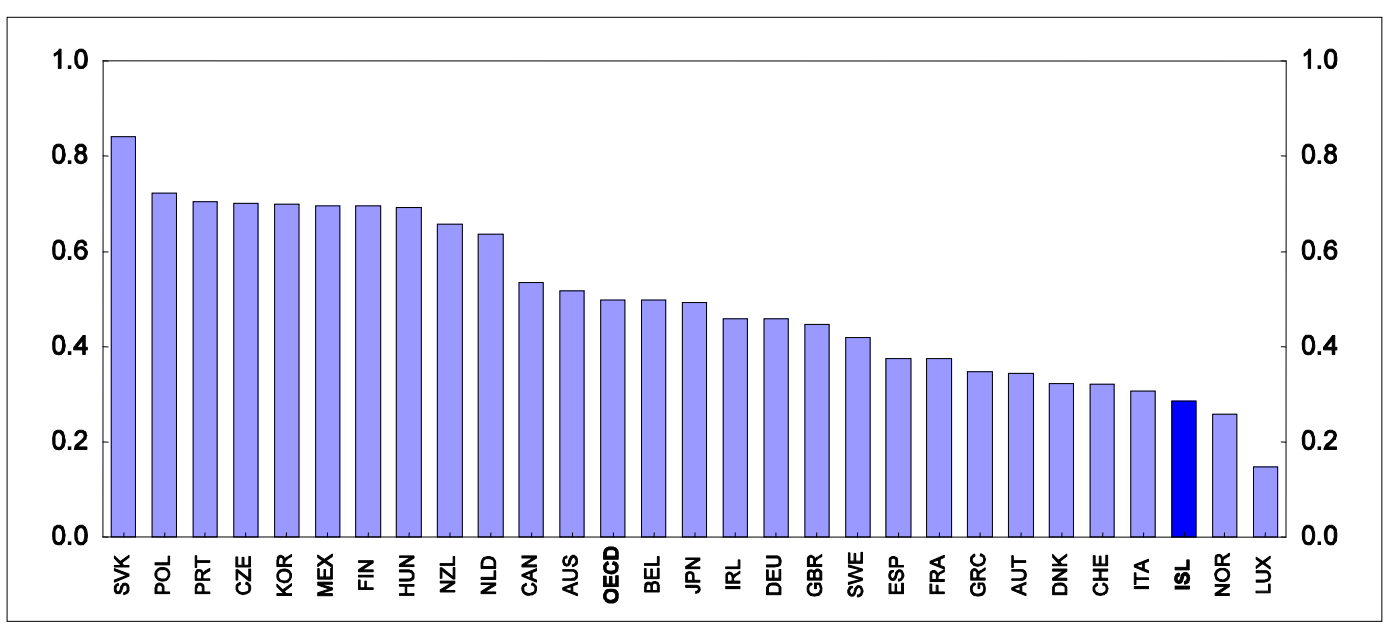

Source: Schwellnus (2009) using OECD, World Bank, World Development Indicators database; FAO, Faostat database.

Table 4. Local government finances

Percentage of GDP

\begin{tabular}{lcc:cc|}
\hline & $\mathbf{1 9 9 5 - 0 2}$ & $\mathbf{2 0 0 3 - 0 6}$ & $\mathbf{2 0 0 7}^{\mathbf{1}}$ & $\mathbf{2 0 0 8}^{\mathbf{1}}$ \\
\hline Revenue & 10.7 & 12.5 & 14.1 & 12.9 \\
Expenditure & 11.3 & 12.8 & 13.4 & 13.5 \\
Financial balance & -0.6 & -0.3 & 0.6 & -0.6 \\
\hline
\end{tabular}

1. Preliminary figures for 2007 and 2008.

Source: Ministry of Finance, May (2009).

75. These considerations indicate that it is important to improve the budgeting process at the local level and institutionalise the co-operation across levels of government. In 2007, the Ministry of Finance began negotiations with the municipalities to address these issues. In exchange for debt relief and increased transfers, the Ministry proposed the introduction of ceilings on real expenditure growth and the level of debt as well as a balanced budget requirement over the business cycle. Unfortunately, little progress has been made so far, but, as argued in the 2008 OECD Survey, the case for extending fiscal rules to municipalities is sound. Indeed, the current dire situation of public finances as well as the medium-term goal of euro-area entry only reinforces the arguments for sub-national fiscal rules.

76. An important obstacle to the introduction of local fiscal rules is the minuscule size of many municipalities, which prevents the adoption of innovation in public management since their implementation costs become excessive relative to the resulting savings. There are still 78 municipalities in Iceland, with large differences in size between them. Reykjavik counts for over one-third of the population, while over one-half of the municipalities have less than 1000 inhabitants. It is therefore crucial to accelerate the amalgamation process, or at least combine the budgeting process of the smallest local authorities. Notwithstanding this concern, introducing sub-national fiscal rules could provide the means for achieving the efficiency gains of local autonomy as well as ensuring that national spending objectives are met. Rules should be designed to take into account changes in population and costs resulting from new central government legislation. Furthermore, credible enforcement mechanisms should be set in place. Also for this reason, ceilings, as for the central government, should be set in nominal rather than real terms and for a specific multi-year period rather than over an undefined business cycle. 


\section{The crisis is an opportunity to reduce wasteful spending}

77. The need to reduce public expenditures should prompt policy makers to close down, or at least scale back those public programmes that do not adequately support the welfare of the general public. The agricultural support programme ranks high on that list: it represents an impediment to structural change and imposes a heavy burden on taxpayers and consumers. Total on-budget transfers to farmers amount to about $1 \%$ of GDP, almost as much as the percentage contribution of agriculture to GDP. After declining in the 1990s, producer support has changed little and was the highest in the OECD in 2007 (Table 5). Prices received by farmers are about $2 \frac{1}{2}$ times higher than those in the world market. Consequently, farm receipts are about 3 times higher than they would be at world prices. The share of the most distorting payments (based on commodity output and non-constrained variable input use) is still nearly $80 \%$. Although annual payments to milk producers have been gradually decreased in line with the 2005 agreement between the government and the farmers' association, further efforts are required to reduce agricultural support.

Table 5. Agriculture: Producer support estimate ${ }^{1}$

As a per cent of gross farm receipts

\begin{tabular}{lcccc}
\hline & $\mathbf{1 9 8 6 - 8 8}$ & $\mathbf{2 0 0 5}$ & $\mathbf{2 0 0 6}$ & $\mathbf{2 0 0 7}$ \\
\hline Australia & 7 & 4 & 6 & 6 \\
Canada & 36 & 22 & 23 & 18 \\
European Union & 40 & 32 & 31 & 26 \\
Iceland & 76 & $\mathbf{7 0}$ & $\mathbf{6 8}$ & $\mathbf{6 1}$ \\
Japan & 64 & 54 & 51 & 45 \\
Korea & 70 & 62 & 63 & 60 \\
Mexico & 28 & 13 & 15 & 14 \\
New Zealand & 10 & 1 & 1 & 1 \\
Norway & 70 & 67 & 65 & 53 \\
Switzerland & 77 & 68 & 62 & 50 \\
Turkey & 16 & 25 & 20 & 21 \\
United States & 22 & 15 & 11 & 10 \\
OECD & 37 & 28 & 26 & 23 \\
\hline
\end{tabular}

1. The monetary value of transfers from consumers and budgetary payments to producers.

Source: Agricultural Policies in OECD Countries: Monitoring and Evaluation, 2008.

78. More generally, the government needs to take responsibility for cutting expenditures and raising taxes, even if that may entail difficult political decisions. And there is little doubt that achieving the fiscal consolidation objectives agreed with the IMF will be very difficult. To this end, Table 6 presents some rough estimates of some the consolidation measures that have been proposed in this paper. It should be noted that these measures fall short from the government's objectives. Therefore, it is even more important that the government soon announces a comprehensive and detailed fiscal consolidation plan for the next few years. The plan should be agreed by all members of government and by the Parliamentary majority that supports the government. As discussed above, the plan should also set multi-year frames in nominal terms for each ministry. Finally, following the lead of Ireland, the government should consider setting up a committee of outside experts to review the plan. The committee should examine if the plan is credible, what needs to be done to implement it successfully and how, if necessary, it should be improved. 
Table 6. Estimated savings for selected fiscal consolidation measures

\begin{tabular}{|c|c|c|}
\hline & $\begin{array}{l}2009 \text { ISK } \\
\text { (billions) }\end{array}$ & $\%$ of 2009 GDP \\
\hline \multicolumn{3}{|l|}{ Revenue-boosting measures: } \\
\hline Increase personal income tax rate by $5 \%$ & 30 & 2 \\
\hline Increase corporate tax rate by $10 \%$ & 10 & $3 / 4$ \\
\hline Increase reduced VAT rate from $7 \%$ to $14 \%$ & 4 & $1 / 4$ \\
\hline Introduce a carbon tax ${ }^{1}$ & 10 & $3 / 4$ \\
\hline \multicolumn{3}{|l|}{ Cost-cutting measures: } \\
\hline Reduce public-sector wage bill by $5 \%$ & 10 & $1 / 2$ \\
\hline Reduce public investment to $1 \%$ of GDP & 15 & 1 \\
\hline $\begin{array}{l}\text { Introduce cost-cutting reforms in health care to raise spending efficiency } \\
\text { to the level of the first quartile OECD-member country }\end{array}$ & $20-25$ & $1 \frac{1}{2}$ \\
\hline $\begin{array}{l}\text { Introduce cost-cutting reforms in education to raise spending efficiency } \\
\text { to the level of the OECD average }\end{array}$ & $20-25$ & $1 \frac{1}{2}$ \\
\hline Eliminate agricultural subsidies & 10 & $3 / 4$ \\
\hline Memo: Average annual fiscal savings goals until 2013 & 60 & 4 \\
\hline $\begin{array}{l}\text { Applying a price of } € 100 \text { per metric ton of CO2. (In Sweden, the carbon tax } \\
€ 108 \text { in 2009.) }\end{array}$ & gradually & d from $€ 27$ in 199 \\
\hline
\end{tabular}

\section{Concluding remarks}

79. Iceland is facing extremely difficult times after having been hit by converging adverse developments, some in reaction to excesses during the past economic boom, others more exogenous. In the past, the Icelandic economy has proven resilient in times when economic circumstances have suddenly changed. While the economy's flexibility is now being tested, an adequate policy response would help to revamp growth, enabling companies to expand investment and create new jobs. To this end, the domestic authorities should aim at quickly restoring the economy to balance and laying out the foundations for a sustainable recovery. This includes stabilising the exchange rate and inflation, and also implementing a decisive fiscal consolidation programme. Box 5 offers more detailed policy recommendations along these lines. 


\section{Box 5. Policy recommendations for monetary and fiscal policies}

Monetary policy: Inflation had been high and volatile even before the recent spike resulting from the collapse of the banks late last year. Facing difficult challenges, including the management of the financial crisis and laying the foundations for a sustainable recovery, the monetary authority should consider the following:

- $\quad$ Keep capital controls in place until they can be safely removed. Until then, monetary policy should continue to be mainly focused on exchange rate stability, which may limit the scope for further reductions in the interest rate.

- $\quad$ Take measures to restore the credibility of the Central Bank. Best-practice policies should be adopted in terms of communication, independence, governance and monetary control. Even more importantly, the conduct of monetary policy should be decisive and members of government should respect the independence of the Central Bank.

- If the EU application process is successfully completed, seek to become a member of the euro area as soon as feasible, and thus reap the economic benefits of the ECB credibility and EMU membership.

- $\quad$ Once capital controls have been lifted, a suitably modified inflation-targeting framework can act as an effective nominal anchor for monetary policy towards euro-area membership. To this end, shift to targeting the harmonised CPI (HICP), which will be the measure for the inflation criterion for euro-area entry.

Fiscal policy: The collapse of the banking sector and economic activity has put public finances in a dire situation. An aggressive fiscal consolidation programme should be quickly implemented to keep the public deficit in conformity with the IMF's Stand-By Arrangement and to pave the road for euro-area membership. This will involve significant tax increases and spending cuts, with the latter playing an increasing role over time.

- Many of the tax cuts implemented over the boom years should be withdrawn, as planned.

- The tax system should be reformed over time in order to increase revenues in a growth friendly way by widening tax bases, imposing corrective taxes and closing loopholes. For instance, the number of goods and services exempt from the VAT should be reduced and a carbon tax should be introduced. There is also scope to better target tax allowances, in particular the interest rate deductions as well as the maternity and child benefit, to lower-income households.

- In the near term, halt all non-essential public infrastructure projects and impose a freeze, or even a cut, on nominal wages in the public sector.

- $\quad$ Adopt a new fiscal framework emphasising spending control and medium-term sustainability, by requiring public agencies to make up for any over expenditure in the following years and giving public-sector managers greater autonomy and accountability in deciding how to achieve their objectives.

- Implement past OECD recommendations in the areas of education and health care to improve the efficiency of such spending. In particular, increase the student-to-teacher ratio, bring the length of studies in line with international standards, and allow higher-education institutions to impose students' fees. Savings can also be made by promoting generic drugs and by increasing cost sharing, especially in hospitals.

- A time of crisis provides the opportunity for introducing politically difficult reforms. Above all, there is scope to cut a number of inefficient programmes, starting with the agricultural subsidies. Similarly, the consolidation process among municipalities could be accelerated. 
ECO/WKP(2009)67

\section{Bibliography}

Alesina, A., R. Barro and S. Tenreyro (2002), “Optimal Currency Area”, NBER Working Papers, No. 9072.

Afonso, A., L. Schuknecht and V. Tanzi (2005), "Public Sector Efficiency: An International Comparison”, Public Choice, Vol. 123.

Aoki, K. (2001), “Optimal Monetary Policy Response to Relative Price Changes”, Journal of Monetary Economics, No. 48, pp. 55-80.

Bassanini, A. and E. Ernst (2002), "Labour Market Institutions, Product Market Regulation, and Innovation : Cross Country Evidence”, OECD Economics Department Working Papers, No. 316.

Bayoumi, T. and B. Eichengreen (1992), “Shocking Aspects of European Monetary Unification”, NBER Working Papers, No. 3949.

Bayoumi, T. and B. Eichengreen (1999), "Operationalising the theory of optimum currency areas", in Cohen, D., A. Sapir and A. Venables (eds.), Market integration, regionalism and the global economy, chapter 7, CEPR.

Bertola G. (1993), "Models of Economic Integration and Localized Growth”, in Torres, F. and F. Giavazzi (eds.), Adjustment and Growth in the European Monetary Union, Cambridge University Press.

Blanchard, O. and J. Tirole (2003). "Redesigning the Employment Protection System", Economist, Vol. 152, pp. 1-20.

Blanchard, O. and J. Tirole (2008), “The joint design of unemployment insurance and unemployment protection: a first pass”, Journal of the European Economic Association, Vol. 6, No. 1, pp. 45-77.

Blondal, S., S. Field and N. Girourard (2002), "Investment in Human Capital through Upper Secondary and Tertiary Education”, OECD Economic Studies, No. 34.

Bravo-Ortega, C. and J. di Giovanni (2006), "Remoteness and Real Exchange Rate Volatility”, IMF Staff Papers, Vol. 53, pp. 115-132.

Breedon, F. and T. Pétursson (2005). "Out in the cold? Iceland's trade performance outside the European Union and European Monetary Union”, Cambridge Journal of Economics, pp. 1-14, doi:10.1093/cje/bei105.

Brook, A. (2005), "The Challenges of EMU Accession Faced by Catching-up Countries: A Slovak Republic Case Study", OECD Economics Department Working Papers, No. 444, OECD Publishing. doi:10.1787/076028301141.

Brixiova, Z., M. Morgan and A. Woergoetter (2009), "Business cycle synchronization and the currency board in Estonia”, OECD Economics Department Working Papers, forthcoming. 
Buiter, W. (2000), “Is Iceland an optimal currency area?”, in Gudmundsson, M., T. Herbertsson and G. Zoega (eds.), Macroeconomic policy; Iceland in an era of global integration, University of Iceland Press, pp. 33-55.

Carey, David (2009), “Iceland: the financial and economic crisis”, OECD Economics Department Working Papers No. 725.

Central Bank of Iceland (2001), Declaration on inflation target and a change in the exchange rate policy, available at www.sedlabanki.is/?PageID=522.

Central Bank of Iceland (2009), Monetary Bulletin, 2009, Vol. 2, pp. 5-62.

Christensen, A., J. Dupont and P. Schreyer (2005), "Inflation Measures: Too High - Too Low Internationally Comparable?”, seminar presentation, Statistics Directorate, OECD.

Clarida, R. and D. Waldman (2008), “Is Bad News about Inflation Good News for the Exchange Rate?”, in Campbell, J. (ed.), Asset Prices and Monetary Policy, University of Chicago Press.

Devereux, M. and P. Lane (2003), "Understanding bilateral exchange rate volatility", Journal of International Economics, Vol. 60, No. 1, pp. 109-132.

Elíasson, L. and T. Pétursson (2009), “The residential housing market in Iceland: Analysing the effects of mortgage market restructuring”, Housing Studies, Vol. 24, pp. 25-45.

European Commission (2004), Convergence Report 2004: Technical Annex, A Commission Services Working Paper.

European Commission (2009), Green Paper: Reform of the Common Fisheries Policy,

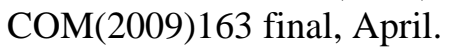

Flamm, H., A. Fátas, S. Holden, T. Jappelli, I. Mihov, M. Pagano, C. Wyplosz (2008), "EMU at Ten Should Denmark, Sweden and the UK join?”, SNS Economic Policy Group Report, SNS Forlag.

Fontagné L., and M. Freudenberg (1999), “Endogenous Symmetry of Shocks in a Monetary Union”, Open Economies Review, Vol. 10, No. 3, pp. 263-287.

Frankel, J. and A. Rose (1997), "The Endogeneity of the Optimum Currency Area Criteria", CEPR Discussion Paper Series, No. 1473.

Frankel, J. and A. Rose (2000), “An Estimate of the Effects of Currency Unions on Trade and Growth", mimeo, first draft May 1, revised June 6, 2000, available at: http://ksghome.harvard.edu/ jfrankel/

Fry, M., D. Julius, L. Mahadeva, S. Roger and G. Sterne (2000), "Key issues in the choice of monetary policy framework", in Mahadeva, L. and G. Sterne (eds.), Monetary Policy Frameworks in a Global Context, Routledge, Centre for Central Bank Studies, Bank of England.

Giavazzi, F. and M. Pagano (1988), “The Advantage of Tying One’s Hands, EMS Discipline and Central Bank Credibility”, European Economic Review, Vol. 32, pp. 1055-1082.

Gust, C. and J. Marquez (2002), "'International Comparisons of Productivity Growth: The Role of Information Technology and Regulatory Practices”, Labour Economics, Vol. 11, pp. 33-58. 
Krugman, P. (1993), "Lessons of Massachusetts for EMU”, in Torres, F. and F. Giavazzi (eds.), Adjustment and Growth in the European Monetary Union, Cambridge University Press.

Huefner, F. and I. Koske (2008), “The Euro Changeover in the Slovak Republic: Implications for Inflation and Interest Rates”, OECD Economics Department Working Papers, No. 632.

IMF (2007), Iceland: 2007 Article IV Consultation-Staff Report; and Public Information Notice on the Executive Board Discussion, IMF Country Report, No. 07/295, August.

Joumard, I., C. André, C. Nicq and O. Chatal (2008), "Health status determinants: lifestyle, environment, health care resources and efficiency”, OECD Economics Working Papers, No.627, OECD Publishing.

McCallum, J. (1995), "National Borders Matter: Canada - US Regional Trade Patterns”, American Economic Review, Vol. 85, No. 3, pp. 615-623.

Mélitz, J. (2001), “Geography, Trade and Currency Union”, CPER Discussion Paper Series, No. 2987.

Ministry of Finance (2009), The Icelandic Economy, Spring.

Mishkin, F. (2008), "Exchange Rate Pass-through and monetary policy“, NBER Working Papers, No. 13889.

Mongelli, F. (2002), ““New” views on the optimum currency area theory: what EMU is telling us?”, ECB Working Paper Series, No. 138.

Nickell, S. and R. Layard (1998), "Labour Market Institutions and Economic Performance", in Ashenfelter, O. and D. Card (eds.), Handbook of Labor Economics, Vol. 3, chapter 46, pp 3029-3084.

OECD (1997), Towards Sustainable Fisheries: Economic Aspects of the Management of Living Marine Resources, OECD Publishing.

OECD (2004), Employment Outlook, OECD Publishing.

OECD (2006), OECD Economic Surveys, Iceland, OECD Publishing.

OECD (2008), OECD Economic Surveys, Iceland, OECD Publishing.

OECD (2009a), OECD Economic Surveys, Estonia, OECD Publishing.

OECD (2009b), OECD Economic Surveys, Mexico, OECD Publishing, forthcoming.

Oygard, S. (2009), Address to the 48th Annual Meeting of the Central Bank of Iceland, Central Bank of Iceland, available at www.sedlabanki.is/lisalib/getfile.aspx?itemid=6940.

Persson, T. (2001), “Currency Unions and Trade: How Large is the Treatment Effect?”, Economic Policy, Vol. 16, No. 33, pp. 433-462.

Pétursson, T. (2000), "New focuses in central banking: Increased independence, transparency and accountability”, Monetary Bulletin, 2000, Vol. 4, pp. 45-57. 
Pétursson, T. (2008), "How hard can it be? Inflation control around the world", Central Bank of Iceland Working Papers, No. 40.

Rose, A. (2000), "One Money, One Market: Estimating the Effect of Common Currencies on Trade", Economic Policy, Vol. 30, pp. 9-45.

Rose, A. and E. van Wincoop (2001), "National Money as a Barrier to Trade: the Real Case for Currency Union”, American Economic Review (Papers and Proceedings), Vol. 91, No. 2, pp. 386-390.

Schwellnus, C. (2009), “Achieving higher performance: Enhancing spending efficiency in health and education in Mexico”, OECD Economics Department Working Papers, forthcoming.

Schmidt-Hebbel, K. (2006) "New Zealand's monetary and exchange-rate policy in international comparison”, in Buckle, B. and A. Drew (eds.), Testing stabilisation policy limits in a small open economy: proceedings from a macroeconomic policy forum, Reserve Bank of New Zealand and the New Zealand Treasury.

Simar, L. and P. Wilson (1998), "Sensitivity analysis of efficiency scores: How to bootstrap in nonparametric frontier models”, Management Science, Vol. 44, pp. 49-61.

Simar, L. and P. Wilson (2000), "Statistical inference in nonparametric frontier models: The state of the art”, Journal of Productivity Analysis, Vol. 13, pp. 49-78.

Suppanz, H. (2006), “Adapting the Icelandic Education System to a Changing Environment”, OECD Economics Department Working Papers, No. 516, OECD Publishing. doi:10.1787/418774783534.

Suppanz, H. (2008), "Improving Cost-Effectiveness in the Health Care Sector in Iceland", OECD Economics Department Working Papers, No. 645, OECD Publishing, doi:10.1787/235327525311.

Sutherland, D., I. Joumard and C. Nicq (2007), "Performance indicators for public spending efficiency in primary and secondary education”, OECD Economics Department Working Paper, No. 546, OECD Publishing.

Yellen, J. (2009), “A Minsky Meltdown: Lessons for Central Bankers”, Presentation to the 18th Annual Hyman P. Minsky Conference on the State of the US and World Economies "Meeting the Challenges of the Financial Crisis", organized by the Levy Economics Institute of Bard College, New York City, April.

Woodford, M. (2003), Interest and Prices: Foundations of a Theory of Monetary Policy, Princeton University Press. 


\section{WORKING PAPERS}

The full series of Economics Department Working Papers can be consulted at www.oecd.org/eco/working_papers/

725. Iceland: The Financial and Economic Crisis (August 2009) David Carey

724. The role of transparency in the conduct of monetary policy (September 2009) Makoto Minegishi and Brosi Cournède

723. Raising education outcomes in Greece (September 2009) Vassiliki Koutsogeorgopoulou

722. Improving the performance of the public health care system in Greece (September 2009) Charalampos Economou and Claude Giorno

721. Is there a case for price-level targeting? (August 2009) Boris Cournède and Diego Moccero

720. The challenge of restoring French competitiveness (August 2009) Rafal Kierzenkowski

719. Improving the functioning of the Slovenian labour market (August 2009) Isabell Koske

718. What drives sovereign risk premiums? An analysis of recent evidence from the Euro Area (July 2009) David Haugh, Patrice Ollivaud, and David Turner

717. The English National Health Service: an economic health check (July 2009) Peter Smith and Maria Goddard

716. Financial stability in the United Kingdom: Banking on prudence (July 2009) Philip Davis

715. Economic growth and the role of taxation- disaggregate data (July 2009) Gareth D. Myles

714. Economic growth and the role of taxation - Aggregate data (July 2009) Gareth D. Myles

713. Economic growth and the role of taxation - Theory (July 2009) Gareth D. Myles

712. The effectiveness of education and health spending among Brazilian municipalities (July 2009) Luiz de Mello and Mauro Pisu

711. The bank lending channel of monetary transmission in Brazil: A VECM approach (July 2009) Luiz de Mello and Mauro Pisu 
710. How does decentralised minimum-wage setting affect unemployment and informality? The case of Indonesia (July 2009) Margherita Comola and Luiz de Mello

709. Intergenerational social mobility in European OECD countries (July 2009) Orsetta Causa, Sophie Dantan and Åsa Johansson

708. Equity in student achievement across OECD countries: an investigation of the role of policies (July 2009) Orsetta Causa and Catherine Chapuis

707. Intergenerational social mobility (July 2009) rsetta Causa and Åsa Johansson

706. Taxes or grants: what revenue source for sub-central governments? (July 2009) Hansjörg Blöchliger and Oliver Petzold

705. The spending power of sub-central governments: a pilot study (July 2009) Steffen Bach, Hansjörg Blöchliger and Dominik Wallau

704. Price and volume elasticities of Brazilian foreign trade: A profit function approach (July 2009) Luiz de Mello and Mauro Pisu

703. Current account sustainability in Brazil: A non linear approach (July 2009) Luiz de Mello and Matteo Mogliani

702. The incentives to participate in and the stability of international climate coalitions: a game-theoretic approach using the WITCH Model (July 2009) Valentina Bosetti, Carlo Carraro, Enrica De Cian, Romain Duval, Emanuele Massetti and Massimo Tavoni

701. The economics of climate change mitigation: how to build the necessary global action in a costeffective manner (June 2009) Jean-Marc Burniaux, Jean Chateau, Rob Dellink, Romain Duval and Stéphanie Jamet

700. Capital inflows, household debt and the boom bust cycle in Estonia (June 2009) Zuzana Brixiova, Laura Vartia and Andreas Wörgötter

699. The effect of financial crises on potential output: new empirical evidence from OECD countries (May 2009) Davide Furceri and Annabelle Mourougane

698. Employment - productivity trade-off and labour composition (May 2009) Hervé Boulhol and Laure Turner

697. Labour market flexibility in Estonia: what more can be done? (May 2009) Zuzana Brixiova

696. Structural policies to overcome geographic barriers and create prosperity in New Zealand (April 2009) Yvan Guillemette

695. Ten years of product market reform in OECD countries - insights from a revised PMR indicator (April 2009) Anita Wölfl, Isabelle Wanner, Tomasz Kozluk and Giuseppe Nicoletti 